\title{
IS HIGHER GOVERNMENT EFFICIENCY BRINGING ABOUT HIGHER INNOVATION?
}

\author{
Jun $\mathrm{WEN}^{1}$, Peidong DENG ${ }^{1}$, Qianxiao ZHANG ${ }^{1}$, Chun-Ping CHANG ${ }^{\text {(D) }}{ }^{\star}$ \\ ${ }^{1}$ School of Economic and Finance, Xian Jiaotong University, Xian, Shaanxi, China \\ ${ }^{2}$ Shih Chien University Kaohsiung Campus, Kaohsiung, Taiwan
}

Received 09 July 2020; accepted 23 December 2020

\begin{abstract}
This research analyzes the impact of government effectiveness on innovation by using unbalanced panel data from the World Bank on 166 countries spanning 1996 to 2018 . We analyze the impact of government efficiency on innovation through various panel fixed-effects models, while incorporating control variables such as GDP, education, and industrial structure into the analysis framework. The empirical results conclude that, in our selected countries, government efficiency has a significantly positive impact on innovation output and more importantly verify the positive impact from the improvement of bureaucracy quality on innovation. The evidence again shows the positive impacts of government efficiency on innovation output by addressing endogenous and robustness checking via the series of methods. Furthermore, the heterogeneity and mechanism of this relationship would be explored. Therefore, the research results provide an alternative method for national governments to promote innovation output by improving government effectiveness.
\end{abstract}

Keywords: government efficiency, innovation output, patents, fixed effect.

JEL Classification: H21, P26, O38.

\section{Introduction}

Since the start of the $21^{\text {st }}$ century, technological innovation as an important approach has attracted attention from many national countries looking to enhance their levels of growth and quality for their economies (Aghion et al., 2007). There is also more evidence that regions with active innovation and entrepreneurship have more late-moving advantages during the process of economic development (Furman et al., 2002). Furthermore, the Institutional School believes that economic growth is attributed to institutional optimization (Fuenfschilling \& Truffer, 2014). Thus, scholars focus more on a government's various policies and the improvement of related systems by various countries, but there is a lack of understanding on related issues concerning the influence of the implementation of policies on innovation

*Corresponding author. E-mail: cpchang@g2.usc.edu.tw 
activities, and imperfect implementation of the regulations will hinder innovation activities (Wang et al., 2020). As this view has been widely accepted, this study investigates a relationship between government efficiency and innovation output. This research fills the gap in exploring the path of innovation promotion from the perspective of the overall institution of government and provides a fresh view of the political economy.

Previous scholars believe that increasing innovation output is one way to increase total factor productivity and thereby promote high-quality economic development (Pradhan et al., 2016). Therefore, how to improve innovation output has become an urgent issue for most countries (Romer, 1990). However, government behaviors always play the decided role in choosing the directions of innovation. Specifically, we study innovation output from the perspective of government effectiveness mainly due to the following four reasons. First, if it is possible to clarify the role of government effectiveness in innovation, then enhancing the innovative level can be achieved by improving government efficiency (Dolfsma \& Seo, 2013). Second, by considering the potential relationship between innovation and economic development, studying the influence of government efficiency on innovation will also provide a reference for policymakers to formulate adaptive policies at various phases of economic development (Dong \& Martin, 2017). Third, increasing innovation output in countries can raise productivity and win greater potential for sustainable development, while also reducing dependence on advanced technologies in developed countries (Farre-Mensa et al., 2020). Finally, it is an argument that "a better effective government benefits the promotion of innovation" indicates that this study enriches the content of the innovation economy in a governance regulation (Hung \& Chou, 2013).

Some pieces of evidence have illustrated that innovation policies are conducive to increasing the outputs of patents and trademarks. For example, based on OECD national data, Acemoglu et al. (2019) finds that when policymakers recognize that technological innovation can help boost the latecomer advantage of economic growth, the significant positive effect shows up clearly on innovation output via a series of incentive policies. Additionally, Nelson (2000) believes that a well-designed policy can increase the productivity of innovation, but the positive effects of the policy gradually diminish for poorly implemented policies. Moreover, inefficient governments can lead to policy failure. The main reason is that too long approval time for technological innovation projects to complete technological innovation investment on time (Duygun et al., 2016). More precisely, excessive contract restrictions, government intervention, and the uncertainty of potential returns have a negative impact on the enthusiasm of technological innovation (Hudson \& Minea, 2013). As a provider of social public services and a regulator of social conflicts, government work efficiency will significantly affect the living quality of residents. For individual innovation activities, the government will promote the innovation output by protecting the interests of inventors and providing a reasonable institutional environment for innovation activities (Tang, 2012). In addition, enterprises as the main force of technological innovation, on the one hand, the government creates a stable innovation incentive mechanism and institutional guarantee for private enterprises to promote enterprises to increase investment in research and development (Musiolik et al., 2020). On the other hand, the improvement of government efficiency will also urge the reformation of state-owned enterprises and guide state-owned enterprises 
to convert monopoly income into innovative capital. Thus, the creation of an effective administrative system may stimulate innovation productivity improvement and enhance the influence of an innovation promotion policy.

However, it is probable that the endogenous problem exists among variables indeed. For example, reverse causality is likely to run from innovation output to government efficiency. On the one hand, due to high information barriers in a government management system, the efficiency of government governance will recede ( $\mathrm{Li}$ et al., 2017). Therefore, improving the level of digital innovation not only can reduce information asymmetry between departments, but can also improve the emergency response capability of the government (Picazo-Tadeo et al., 2012). In general, the funding for most technological innovation projects comes from government subsidies. Therefore, the efficiency of administrative approval largely affects the rate of return on innovation projects and the productivity of innovation results (Murphy et al., 1993). On the other hand, by considering that higher innovation output also benefits several sectors such as agriculture and industry, then improving innovation output will also increase the operating efficiency and productivity of these sectors (Samara et al., 2012). Therefore, in order to improve the output of innovation, more effective policies should be implemented by effective governments.

By employing the panel fixed, and dynamic GMM as well as the Poisson regression, the present research specifically explores the association between government efficiency and innovation for 166 countries over the past nearly four decades. Furthermore, the dynamic estimation helps us to address the potential endogenous problem. To ensure robustness, this study employs two indicators of government effectiveness. This first is "government efficiency" taken from Worldwide Government Indicator (WGI); the second measure reflects Bureaucracy Quality, with data collected from the International Country Risk Guide (ICRG). Besides, we utilize measures for innovation output, which are patents and trademarks, whose data are from the World Intellectual Property Organization (WDI). To explore the data further, we hence divide the full sample into four sub-groups: European countries, former Communist countries, top-10 patent output countries, and OECD countries. In sum, comparing with the existing literature, this study investigates an association between government efficiency and innovation output by adopting static and dynamic models, which could help account for cross-country investigations and address the endogeneity among variables.

The main objective of this paper is to explore the effect of government efficiency on innovation output. We explored the heterogeneity of the relationship between government efficiency and innovation in different countries or international organizations by sub-sample tests and discussed some interesting results. Besides, we not only select traditional agency variables (patents) for innovation but also selected commercial innovation indicators (trademarks) in various regressions. Finally, we verify and discuss how government efficiency impacts innovation output from the perspective of the institutional environment. Additionally, the results achieve consistency among various checking which confirm that high-effective government tend to enhance the innovation level

The remainder of this paper runs as follows. Section 1 is a literature review. Section 2 introduces data and methodology. The empirical results and discussions are exhibited in section 3. Last section draws overall conclusions and puts forward relevant policy suggestions. 


\section{Literature review}

\subsection{The impacts on innovation}

Technological innovation can create a large number of intangible assets and make enterprises more competitive (Hung \& Chou, 2013) and therefore has received increasing attention from governments and enterprises. As innovation activities are significantly affected by the external environment, more scholars have shifted their research focus to factors influencing innovation activities. Anokhin and Wincent's (2012) classification study introduces human capital, physical capital, and institutions as the main impact factors.

Firstly, we divide the analysis of human capital into views of quality and quantity. On the one hand, Dong et al. (2016) argue that increasing the population size leads to diversified needs that guide producers to work for continuous product innovation and to promote technological progress. From another perspective, population growth and population density also increase the possibility of the appearance of geniuses, who might create something new for the world. Lachenmaier and Rottmann (2011) also confirm this view by measuring the contribution of innovation from population growth. On the other hand, some scholars suggest that a higher level of investment in human capital offers value for the innovation process (Kaiser et al., 2015). Hudson and Minea (2013) believe that the accumulation and dissemination of existing knowledge are vital factors for the successful construction of an innovative atmosphere. Furthermore, Lee (2010) claims that larger innovation capacity benefits from the improvement in the absorptive capacity of knowledge. Donou-Adonsou (2019) conducts an empirical analysis of the relationship between education and innovation and concludes that innovative ideas often come from the stimulation of new external knowledge. Secondly, in the aspect of physical capital, similar to the transfer of foreign advanced technology, the spillover effect of foreign direct investment is also a crucial factor for promoting technological progress in the host countries. Audretsch et al. (2014) recommend that foreign businesses transfer knowledge and technology by training local workers. Moreover, local employees can provide more localized and innovative ideas for product development. Baskaran and Muchie (2006) explore the relationship between FDI and innovation and note that the spillover effect of FDI distinctly improves the innovation level of the host country. In the background of industrial changes, the cross-regional transfers of technology, capital, and knowledge magnify the spillover effect, bringing innovational opportunities and motivating local companies to achieve technological innovation (Kogan et al., 2017). Thirdly, from the point of local institutional environment The modification and execution of an industrial policy influence the direction and field of technological innovation, as well as the innovation investment decisions of market entities under powerful governance (Lovett, 2011). Kuhn (2012) points out that research on higher value-added technologies can increase the attractiveness of related technological innovations and form a virtuous circle. Thus, an adaptive innovation environment leads to more innovation output.

\subsection{Government and innovation}

Previous scholars have studied the relationship between governmental power, political connections, and innovation incentive policies. Anokhin and Wincent (2012) takes patent appli- 
cation volume as a criterion for evaluating innovation output and conducts in-depth research on innovation incentive policies. Their result is consistent with Hudson and Minea's (2013) research conclusion. They both believe that the establishment of a cross-sectorial policy and system for technological innovation is a crucial step for the government to support innovation (Flanagan et al., 2011). The government can also improve innovation output by designing a complete innovation compensation mechanism. Bronzini and Piselli (2016) state that local government possesses a driving effect on the regional economy by subsidizing specific high-tech projects. Identically, government power has a significant impact on the direction of technological innovation research for most developing countries, which is similar to the conclusion to that obtained by Godfrey et al. (2002) when studying the role of innovation incentives in economic development and technological innovation. Additionally, previous scholars believe that the incentive policies proposed by parties with different ideologies will also lead to differences in innovation output (Rydgren, 2005). This is reflected in the longterm innovation policies advocated by left-wing parties. On the contrary, a government is more inclined to loosen market control when right-wing parties hold power, which is supported by relevant empirical results (Smith et al., 2010). Similarly, these studies display that policies proposed by left-wing parties are more conducive to technological innovation. This conclusion is consistent with the far-sightedness of left-wing parties in the policymaking process $^{1}$.

Innovation also closely relates to the institutional environment. For example, by studying the relationship between the government and entrepreneurs, Hudson and Minea (2013) conclude that a friendly property rights protection system will help entrepreneurs make technological innovation decisions. Samara et al. (2012) find a non-linear relationship between the intellectual property system and technological innovation, in which excessive intellectual property protection is harmful to technological innovation in developing countries. Therefore, the absence of a formal system is also one of the reasons for the lack of innovative activities in most countries. Moreover, informal institutional constraints such as beliefs, cultures, and values also profoundly impact technological innovation (Kogan et al., 2017). For example, a good innovation atmosphere and a social culture that tolerates failure have important impacts on stimulating innovation. Similarly, improvements in innovation performance are constantly shaping inclusive social values.

Political connections and government intervention are also vital factors in the research of innovation behavior (Lovett, 2011). Under the constraints of limited resources, companies often seek political connections to replace technological innovation for gain (Acemoglu et al., 2019). For most risk-averse companies, seeking political connections can help them to more easily access scarce resources, but this will also cause negative effects from increased rent-seeking costs and government corruption (Murphy et al., 1993). After studying innovative behavior under different contract laws, property rights protection laws, and other legal systems, Lin and Du (2013) obtain in regions and countries where the proportion of state-owned enterprises is relatively high that companies face more hidden barriers in the transformation of innovation achievements. This also inevitably will lead to a crackdown on

\footnotetext{
${ }^{1}$ Belke and Potrafke (2012) note that a right-wing ruling party prefer to choose expansionary economic policies compared with leftist government.
} 
enterprises' enthusiasm for innovation (Anokhin \& Wincent, 2012). The informal institutional constraints embedded in political connections also weaken the innovation enthusiasm of the whole society to a certain extent.

To sum up, most existing relate literature focuses on issues concerning policies that improve innovation output, including innovation incentives, intellectual property regulations, and industry standards. Dolfsma and Seo (2013) target the influence of specific policies on innovation activities. Several associated policies not only stimulate target industries but also reform the innovation system to incentivize innovation output (Samara et al., 2012). Galang (2012) discuss some innovation policies and their implementation effect, but the efficiency of government systems often plays a key role in the implementation of innovative policies. Thus, this study explores how effective government systems can promote innovation output based on data from 166 countries.

\subsection{Hypothesis}

Based on previous relevant literature, we found that innovation is highly relevant to policy. At the same time, whether the innovation policy can play a role depends on the government's efforts to implement it. Due to the lack of incentives, government employees display burnout or are more inclined to abuse their power during the implementation of policies (Glotko et al., 2020). Therefore, government effectiveness may promote innovation output through the impact of policy implementation. Specifically, governments with higher efficiencies tend to support innovation which has more far-sighted employees. These characteristics are benefiting with the prosperity of innovation activities. On the contrary, a low-motivated government prefers to rely on power rent-seeking and monopoly income to maintain its operation, which cannot provide a better environment for innovation activities (Sekmen \& Toptas, 2015). From a social point of view, an effective government can create an open and shared social atmosphere, which will also promote the innovative expression of residents, while an ineffective government will lead to the social atmosphere of fraud and plunder, which will also be detrimental to innovation. Therefore, we propose the following hypothesis.

HP1: The improvement of government efficiency can promote the increase of innovation output.

The impact of the economic system on technological development has attracted the attention of some scholars. Furthermore, it has clarified the mechanism of technological innovation for private and state-owned enterprises through ownership analysis. But the diversity of the economic system stems from the choice of ideology and political system (Wang et al., 2019). Countries with better economic performance are able to support R\&D expenditures and thus obtain the more innovative output. But if the government can mobilize more economic resources to fund innovation activities, it will also lead to more new technology achievement (Angelini et al., 2020). For developed countries in Europe and America, innovation comes more from the spontaneous behavior of enterprises or individuals, which benefits from the market incentive mechanism (Sena et al., 2018). For developing countries that have experienced the period of a planned economy, people generally believe that the government is the protagonist of research and innovation. Therefore, the implementation of policies is 
particularly important in innovation activities. From the above inferences, we expect that comparing with European countries, the former communist countries (FCC) can obtain a larger number of patent and trademark applications by improving government efficiency. Based on the above analysis, we propose Hypothesis 2 for verification.

HP2: FCC can obtain a greater degree of innovation output by improving government efficiency.

Institutional economics divides the system into a formal system and an informal system. The formal system is mainly represented by laws and regulations, while the informal system is mainly represented by beliefs, values, and culture. Since the regulations and laws could do an obvious influence on innovation in the short-term. Thus, the formal institutional environment will be particularly important. The improved institutional environment can stabilize the expectations of entrepreneurs to conduct innovation activities (Sena et al., 2018). Meanwhile, it means that governments would provide entrepreneurs with loose approval processes and reduced transaction costs. The poor institutional environment can only force enterprises to prefer to do unproductive and rent-seeking behaviors. In the previous studies of the relationship between the formal system and innovation, researchers mainly focused on the relationship between a certain regulation or policy and innovation (Kogan et al., 2017). There are few studies that concentrate on the role of the overall institutional environment on innovation. In developing countries, enterprises often encounter difficulties in operating due to ambiguity contract laws, property laws, and other unreasonable regulations (Musiolik et al., 2020). Exactly, the lack of improved systems and the legal environment always cause poor innovation activities. Therefore, the establishment of a perfect formal institutional environment can effectively strengthen the protection of investors and inventors. Thus, we propose the following hypothesis.

HP3: Government efficiency impacts innovation activities by optimizing the institutional environment.

\section{Data and methodology}

In this study, we utilized the unbalanced panel data of Patent, Trademark, FDI, GDP, Education, Industry, Energy, openness, and Population from WDI (2018). The Patent and Trademark are transformed into their natural logarithms as core dependence variables in baseline regression. And the original data of other variables in the models. The empirical period is determined by the availability of data, while we drop those observations that are missing values of the abovementioned variables. We subsequently obtain unbalanced panel data that cover 166 countries from 1996 to 2018.

\subsection{Dependent variables}

Many scholars have focused on the estimation of innovation behaviors. Among them, patents and trademarks are always related to the influence and appearance of new inventions, which are also powerful indicators that show how governments upgrade the degree of innovation 
domestically. Therefore, the number of applications for patents and trademarks ${ }^{2}$ is often used to measure the efficiency of innovation output. In addition, the original form data of applications for patents and trademarks are utilized in Poisson regression as the one of robust checking methods. The major advantages of these two forms of technology recognition are presented as follows.

Patent: Farre-Mensa et al. (2020) points out that patents represent a useful invention that offers insight into regional-level innovation activities. In contrast to the number of granted patents, Jalles (2010) claim that patent applications label the output of the innovation process intermediately. Moreover, Pradhan et al. (2016) suggest that large available databases for patents can be a great type of innovational measurement. Kayal (2016) proposes that a high number of patent applications means that the economy has a greater advantage in sustainable development, which is also the main goal pursued by governments. As such, we follow Chang et al. (2015), who adopt the logarithmic form of the number of patent applications (Patent), to assess the innovation output of a large sample of countries.

Trademark: As Wen et al. (2018a) state, a trademark application is one of the most adaptive measurements of innovation behaviors. The reason why we utilized trademark application as another indicator of innovation is that trademarks represent the degree of industrial innovation and also mark several business phenomena that are not captured by patents. Furthermore, trademark applications have become systematical records for past decades. Thus, various data sources for trademarks are available (Duygun et al., 2016). We utilize the amount of trademark applications (Trademark) in the previous literature as a proxy for innovation (Stim, 2020; Zaichkowsky, 2020). Following Benny (2020), the number of applications for patents and trademarks can come from the World Development Indicator (WDI, 2018) database ${ }^{3}$.

\subsection{Independent variables}

The core explanatory variable is government efficiency in this study. Chang and Lee (2011) claim that two indicators could reflect the effectiveness of government. According to the definition of Wen et al. (2016), the indicators of government efficiency and bureaucracy quality are utilized and described below.

Government efficiency (Goveffect): Accumulated wisdom takes several independent variables into consideration that influence innovation output. We emphasize government efficiency, which may spur innovation output. Wen et al. (2018b) notice that the quality of government impacts the procedure for measuring innovation policies. Hence, we set up a variable "Government Efficiency" that measures the government efficiency (WGI) taken from the World Governance Indicators (WGI, published by the World Bank) to focus on "the

\footnotetext{
2 There are some shortcomings from using one of the indicators of Patent and Trademark. Precisely, due to the patent applications is appropriated to describe several technological problems. And patent always use in manufacture industry. Thus, it difficult to express the innovation output of all economic activities (Audretsch et al., 2014). By contract, Trademark provide some information about slogan brand and logo which is likely to cover the third industry (Mendonça, 2014). Hence, in order to ensure the accuracy of our results, this research employs both Patent and Trademark as indictors to estimate the level of innovation.

3 The total number of application of patent and trademark are assessed from World Bank Indictor.
} 
extent of its independence from political pressure, the quality of the public service and the credibility of issued policy". Government efficiency (WGI) ranges from approximately -2.5 to 2.5 , and a higher value reflects a more effective governance system.

Bureaucracy quality (Bure): Additionally, Bureaucracy Quality (BURE) ${ }^{4}$ provides information regarding the level of a government officer, the structure of government employees, and the efficiency cost of the approval process. In other words, the improvement in government efficiency can be attributed to the reformation of governance structure (Fredriksson \& Svensson, 2003). herefore, Bureaucracy Quality is an appropriate indicator for checking the association between innovation output and government efficiency (Lovett, 2011). To more deeply confirm the robustness of the benchmark results, we define Bureaucracy Quality as an alternative variable to be incorporated into the model with two dependent variables mentioned above.

\subsection{Control variable}

Per capita real GDP (GDP): GDP ${ }^{5}$ usually reflects the overall level of economic growth in a country. Luo and Cheng (2013) confirm that technological innovation requires a well-anticipated social atmosphere provided by overall economic growth. Furthermore, more financial resources could support research fees from economic development. Aghion et al. (2007) set per capita real GDP as the level of economic development. Hence, we follow previous studies and adopt per capita GDP to assess economic growth in the sample countries.

Proportion of the manufacturing industry to GDP (Industry): Changes in industrial structure affect the direction and field of technological innovation, as well as the innovation investment decisions of local governments (Lehmann \& Seitz, 2017). Research on higher valueadded technologies can increase the attractiveness of technological innovations and form a virtuous circle (Geroski \& Walters, 1995). Therefore, following Kayal's (2016) viewpoint, we utilize the value of the manufacturing industry divided by GDP to measure the industrial structure.

Gross secondary school enrollment rate (Education): A higher level of education can also help more people to join in on the research and development of new technologies (Bianchi \& Giorcelli, 2020). Moreover, the flow and availability of knowledge are attributed to knowledge accumulation (Donou-Adonsou, 2019). From another perspective, a higher level of human capital can promote technological innovation output. Following Chi and Qian (2010), we adopt education-year per capita to represent the education level of various countries.

Total export-import volume divided by GDP (Openness): Economic activities, in general, are more active in export-oriented regions, and active trade exchanges have also increased the amount of local governments' current accounts (Dahlander \& Gann, 2010). Therefore, on the one hand, the government can invest in the long-term accumulation of foreign exchange capital in new technology research and development. On the other hand, patents and

\footnotetext{
${ }^{4}$ According to the International Country Risk Guide, Bureaucracy Quality is assessment of government effectiveness which including officer structure, policy implement efficiency and credibility etc.

${ }^{5}$ In accordance with Aghion et al. (2018), the GDP per capita on basis of 2000 US dollars from WDI database.
} 
trademarks are exposed to the risk of having such trade secrets being stolen (Melero et al., 2020). We make use of total export-import volume divided by GDP to measure economic openness as per Murray et al. (2016)

Population density (Population): According to the theory of endogenous economic growth, as an important input factor in the process of economic development, the mass of labor benefits from a higher population density, which promotes total factor productivity (Ziller \& Goodman, 2020). As Dong et al. (2016) note, more innovational inspirations are created within the optimized process for higher population density. However, Parrotta et al. (2014) discover an inverted U-shape relationship between innovation and population. Therefore, we select the number of people per square kilometer as an important indicator of regional human resource supply from the World Bank data in the model.

Ratio of foreign direct investment to GDP (FDI): Many scholars believe that more foreign direct investment (FDI) will spur local industrial upgrading and technological progress. More importantly, foreign capital investment will bring significant spillover effects to the host country via factory construction and employee training (Autor et al., 2016). Conversely, Howell (2020) suggests that a cheaper labor force and larger market scale are mainly for FDI. Thus, the impact of innovational FDI is difficult to quantify. Therefore, this study includes an average annual net foreign direct investment as an indicator (Akisik et al., 2020).

Ratio of energy use to GDP (Energy): Energy is an important resource in the process of economic development. Haas and Kempa (2016) find that traditional energy and technological innovation have a certain degree of substitution and promotion effects during economic development. In areas where traditional energy is more abundant, the large wealth accumulation from energy businesses could support technological innovation (Hille et al., 2020). From the opposite view, the local economy might overly rely on resources and be lazy to work on innovation (Kogan et al., 2017), thus negatively affecting the output of technological innovation. We herein utilize the ratio between energy supply and gross domestic product to measure energy density in the model.

\subsection{Data description}

We check the influence of government efficiency on innovation output using panel data that consist of 166 countries over the period 1996-2018 in List A3. First, we employ the full sample in the estimations. The sample countries are displayed Figures 1 and 2, reflecting their applications of patents and trademarks. We easily see that the spatial distributions in these numbers are basically the same. Obviously, there are significant regional differences in the number of applications. Specifically, China and the United States have the largest numbers of patent and trademark applications, while countries with more trademarks and patents are mainly located in Europe and East Asia. In addition, countries in Africa and Latin America have relatively few innovation outputs.

Appendix Table A2 provides a summary of the descriptive statistics for the data utilized, including their sources and definitions. The positive average government efficiency (WGI) indicates the majority of selected countries have effective governments. In addition, the deviation in the indictor of innovation is about 70000, meaning that the majority of patents and 
trademarks are handled in only a few countries. Additionally, the deviations in population and real per capita GDP illustrate the distribution of wealth and labor vary greatly. We also observe that the average indicators of industry structure and energy density are significantly higher than zero. Compared to openness and FDI, there is a narrow and similar degree of dispersion for energy density and school enrollment. It also suggests several variables varied greatly over time and across countries. The correlation matrix appears in Appendix Table A1. Broadly speaking, the correlation of all variables is not related very much. Hence, multicollinearity may not influence the accuracy of the estimated results.

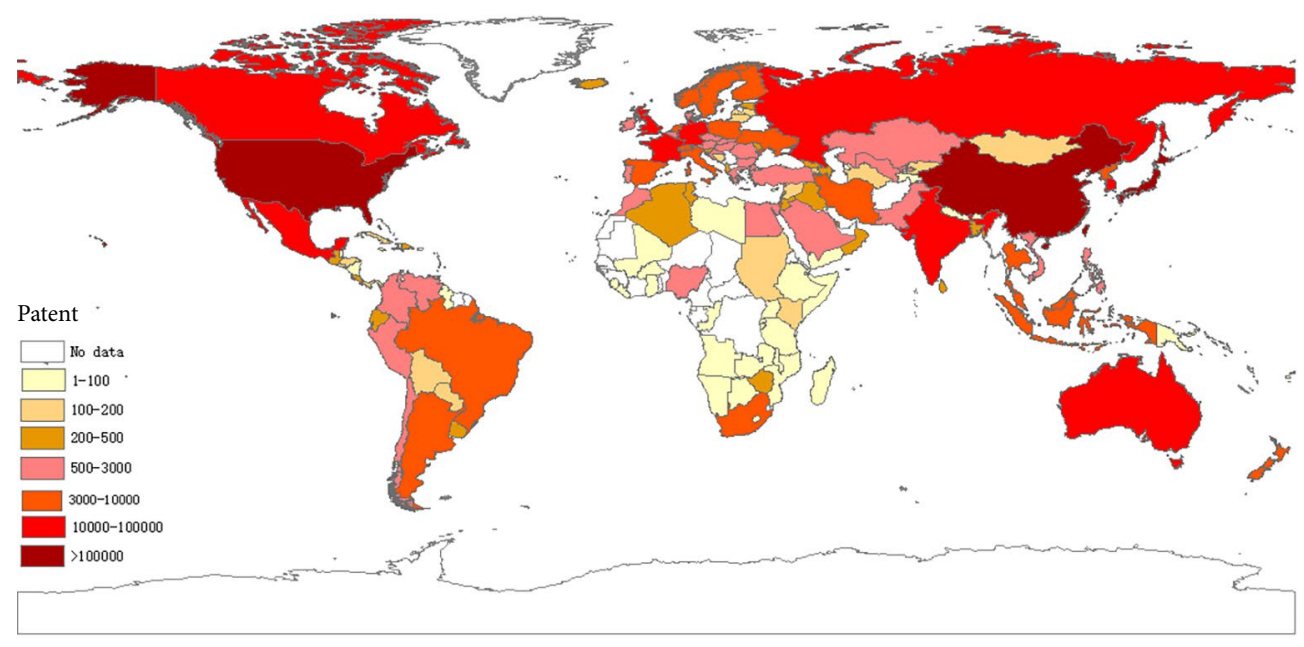

Figure 1. Maps of patents in 2018

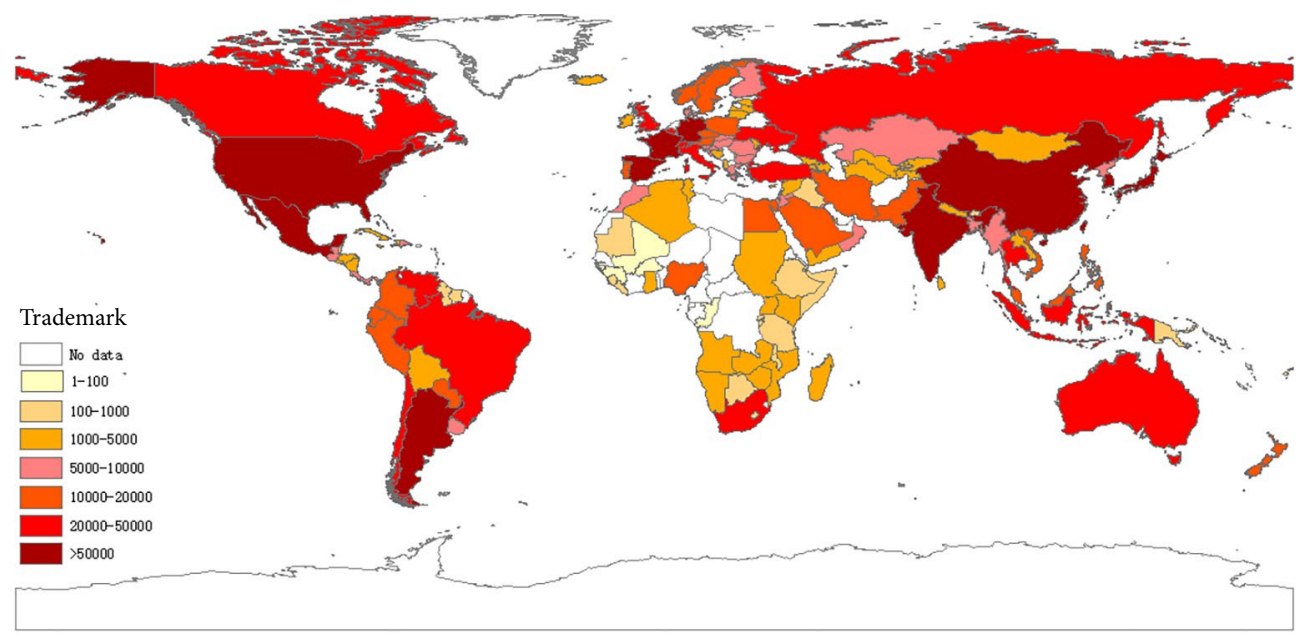

Figure 2. Maps of trademarks in 2018 


\subsection{Empirical methodology}

Owing Wooldridge (2015) argued that panel data with advantages: firstly, panel data provides the solution for the question of missed variables. Secondly, more dynamic information reflects in the panel data. Finally, panel data enlarge the sample capacity compared with time-series data, which is likely to obtain more accurate results. Therefore, in order to investigate the relationship between government efficiency and innovation output. We collect the panel data over the period 1996-2018. Due to several differences among variables. In the estimation, we take the natural logarithm of the dependent variables Patent and Trademark, explanatory variables Goveffect, and several control variables such as GDP per capita, foreign direct investment, energy density, education, industry, and openness. Therefore, this study sets the following panel data model:

$$
\begin{aligned}
& \operatorname{Ln}\left(\text { Patent }_{i, t}\right)=\alpha_{0}+\alpha_{1} \text { Goveffect }_{i, t}+\beta Z_{i, t}+\mu_{i}+v_{i}+\varepsilon_{i, t} ; \\
& \operatorname{Ln}\left(\text { Trademark }_{i, t}\right)=\alpha_{0}+\alpha_{1} \text { Goveffect }_{i, t}+\beta Z_{i, t}+\mu_{i}+v_{i}+\varepsilon_{i, t} .
\end{aligned}
$$

where, Patent and Trademark represent innovation output as the main dependent variables; $Z$ is a vector of control variables that may affect innovation output; $\mu_{i}$ and $v_{i}$ are the fixed effect variables for time and region, respectively; and $\varepsilon_{i, t}$ is the error term.

As a benchmark regression model, the standard fixed effects model provides us with a good set of static estimation processes (Nickell, 1981). Furthermore, the static model does not take into account the endogenous problems that may arise from the mutual impact between government efficiency and innovation output, making the estimation results appear inconsistent. Therefore, in order to solve the endogenous problem in fixed effects, we follow the systematic GMM estimator proposed by Arellano and Bond (1991) and select the lagging period value of the dependent variable as an instrumental variable in the regression model to test endogeneity.

The Generalized method of moments can also deal with autocorrelation and heteroscedasticity problems. During this process, since the correlation between the lag instrument variable and endogenous variables is small, the problem of a weak-instrument variable will be exposed, which will be checked by the Sargan test. Therefore, a dynamic method should be adopted to better analyze the effect of government efficiency on innovation output. The two-step system GMM estimate is shown as:

$$
\begin{aligned}
& \operatorname{Ln}\left(\text { Patent }_{i, t}\right)=\alpha_{0}+\alpha_{1} \operatorname{Ln}\left(\text { Patent }_{i, t-1}\right)+\alpha_{2} \text { Goveffect }_{i, t}+\beta Z_{i, t}+\varepsilon_{i, t} ; \\
& \operatorname{Ln}\left(\text { Trademark }_{i, t}\right)=\alpha_{0}+\alpha_{1} \operatorname{Ln}\left(\text { Trademark }_{i, t-1}\right)+\alpha_{2} \text { Goveffect }_{i, t}+\beta Z_{i, t}+\varepsilon_{i, t} .
\end{aligned}
$$

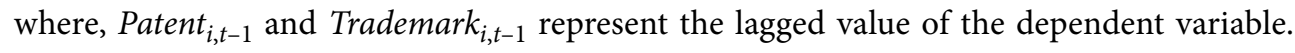
The other variables have the same meaning as above.

\section{Estimation results and discussion}

In this section, our paper provides empirical results for the relationship between government efficiency and innovation output by utilizing various methods. 


\subsection{Basic results}

We first present the results of the panel fixed effect model in Table 1. In the regression, we include a variety of control variables and characterize the relationship between government effectiveness and innovation output from the perspective of patent and trademark applications. Model 1 reports the impact of government effectiveness on innovation output after including indicators of foreign direct investment and GDP per capita. The remaining models add richer control variables to verify this relationship. Among them, Model 4 and Model 8 include all control variables. Several bottom rows of Table 1 exhibit Pearson (2015), Rsquared, and F tests, respectively. Overall, the empirical evidence shows that all regressions pass the fixed effect test, and hence the results support the validity of the determination for sample countries.

Table 1. The Impacts of Government Innovation (WGI) on Innovation (Fixed Effect)

\begin{tabular}{|c|c|c|c|c|c|c|c|c|}
\hline & \multicolumn{4}{|c|}{ LnPatent } & \multicolumn{4}{|c|}{ LnTrademark } \\
\hline & (1) & (2) & (3) & (4) & (5) & (6) & (7) & (8) \\
\hline \multirow{2}{*}{$\begin{array}{l}\text { Government } \\
\text { efficiency }\end{array}$} & $0.17^{\star}$ & $0.28^{\star *}$ & $0.31^{\star * *}$ & $0.33^{\star *}$ & $0.23^{* * *}$ & $0.21^{\star \star *}$ & $0.22^{\star * *}$ & $0.37^{* * *}$ \\
\hline & $(1.85)$ & $(2.12)$ & $(2.61)$ & $(2.04)$ & $(4.82)$ & $(3.43)$ & $(3.94)$ & $(5.72)$ \\
\hline \multirow{2}{*}{ FDI } & 0.09 & -0.30 & 0.17 & -0.52 & 0.02 & 0.09 & 0.04 & -0.27 \\
\hline & $(0.32)$ & $(-0.58)$ & $(0.35)$ & $(-0.85)$ & $(0.15)$ & $(0.39)$ & $(0.20)$ & $(-1.13)$ \\
\hline \multirow{2}{*}{ GDP } & -0.02 & & & $0.90^{* * *}$ & $-0.09^{\star * \star}$ & & & -0.08 \\
\hline & $(-0.67)$ & & & $(3.12)$ & $(-4.27)$ & & & $(-0.77)$ \\
\hline \multirow{2}{*}{ Openness } & & 0.08 & & $-0.53^{\star *}$ & & -0.02 & & -0.14 \\
\hline & & $(0.58)$ & & $(-2.35)$ & & $(-0.37)$ & & $(-1.62)$ \\
\hline \multirow{2}{*}{ Energy } & & $0.08^{* * *}$ & & $0.09^{* * *}$ & & -0.01 & & -0.01 \\
\hline & & $(4.64)$ & & $(2.75)$ & & $(-0.44)$ & & $(-0.75)$ \\
\hline \multirow{2}{*}{ Population } & & & 0.02 & 0.19 & & & $0.04^{\star}$ & $0.16^{* \star *}$ \\
\hline & & & $(0.49)$ & $(1.63)$ & & & $(1.68)$ & $(3.99)$ \\
\hline \multirow{2}{*}{ Education } & & & 0.06 & -0.46 & & & $0.31^{\star * *}$ & $0.73^{* * *}$ \\
\hline & & & $(0.33)$ & $(-1.17)$ & & & $(3.35)$ & $(4.73)$ \\
\hline \multirow{2}{*}{ Industry } & & & -0.12 & -0.94 & & & -0.08 & -0.07 \\
\hline & & & $(-0.29)$ & $(-0.86)$ & & & $(-0.33)$ & $(-0.22)$ \\
\hline \multirow[t]{2}{*}{ Constant } & $-2.61^{\star * *}$ & $-3.04^{* * *}$ & $-2.66^{* * *}$ & $-3.08^{\star * *}$ & $-0.23^{\star * *}$ & $-0.21^{\star * *}$ & $-0.53^{\star \star \star}$ & $-0.92^{\star * *}$ \\
\hline & $(-56.61)$ & $(-18.21)$ & $(-14.59)$ & $(-5.93)$ & $(-9.61)$ & $(-2.87)$ & $(-5.16)$ & $(-4.80)$ \\
\hline $\begin{array}{l}\text { Individual } \\
\text { factor }\end{array}$ & control & control & control & control & control & control & control & control \\
\hline Time factor & control & control & control & control & control & control & control & control \\
\hline $\mathrm{R} 2$ & 0.00 & 0.04 & 0.01 & 0.05 & 0.03 & 0.02 & 0.04 & 0.14 \\
\hline $\mathrm{F}$ & 12.20 & 6.52 & 1.52 & 3.03 & 12.73 & 3.12 & 6.04 & 9.47 \\
\hline
\end{tabular}

Notes: Trademark denotes the total number of trademark applications, while Patent presents the total number of patent applications. Z-statistics in parenthesis; ${ }^{* * *},{ }^{* *}$, and ${ }^{*}$ indicate statistical significance at the $1 \%, 5 \%$, and $10 \%$ levels, respectively. 
We additionally find a positive coefficient of government efficiency at 0.17 , which is significantly different from zero at the $10 \%$ level. It indicates that higher innovation output comes from the increase in government efficiency. In column (4), an increase in government efficiency by one unit enhances patent and trademark applications by 0.33 and 0.37 percentage points, respectively. Moreover, our evidence reflects that government efficiency generates a crucial influence on innovation activities. This result is consistent with Galang (2012), who finds that ineffective governments often damage international technology adoption.

The variable Energy generates a different impact on patent and trademark applications. Columns (2) and (4) show a positive impact on Patent at the $1 \%$ significance level, which implies that higher energy density could boost the activities of the patent application. Conversely, some energy businesses do not promote the benefits of their trademarks at the $1 \%$ significant level. It may be attributed that the large demand for technology innovation from monopoly energy enterprises to improve their productivity, rather than the dissemination of trademarks. These results are in line with Chang et al. (2018), who pay more attention to energy reformation.

\subsection{Robustness check}

In order to address potential endogenous problems, we form a dynamic fixed-effect model between government effectiveness and innovation output, Wen et al. (2018b) find that countries with high levels of innovation output expect to have higher innovation output in the following years. We use the systematic GMM estimation method to simulate the dynamic correlation between government effectiveness and innovation. The coefficients of government efficiency in 1-4 columns are higher than others respectively which suggests that the promoting effect of patent applications from government effect is greater than the trademark. It may be drawn from different verification systems. Adding the lagged value of the dependent variable as one of the explanatory variables will generate the dynamic panel model (Nickell, 1981). The estimation results reveal that AR (2) for most models are not significant at the $10 \%$ level, meaning that the problem of over-identification from the instrument variable is absent. Similarly, we gradually add control variables into columns (1)-(4) in Table 3. From the results of various equations in Table 4 , several alternative conclusions can be drawn. As shown in Table 2, the estimated coefficient of the lagged dependent variable is positive and significant at the $1 \%$ level for all regressions, suggesting that countries with a high level of current innovation tend to promote higher innovation output in the future. In other words, the current innovation output always is original from past innovation behaviors. These results are similar to Wen et al. (2016), who put forward that innovation output exists strong consistency.

We next note evidence that a higher education level is positively associated with improvement in innovation output in all equations. This effect has been confirmed by Ayres et al. (2007), and it means that prosperous innovation activities originally come from the accumulation of human capital. In contrast, the mixed effect happens on the variable GDP. Its coefficient is negative when Openness and Energy are absent from the regression. However, a positive coefficient appears after incorporating the other explanatory variables. It indicates that finance resources support different fields during GDP growth (Pradhan et al., 2016). 
Table 2. The Impacts of Government Efficiency (WGI) on Innovation (SYS-GMM)

\begin{tabular}{|c|c|c|c|c|c|c|c|c|}
\hline & \multicolumn{4}{|c|}{ LnPatent } & \multicolumn{4}{|c|}{ LnTrademark } \\
\hline & (1) & (2) & (3) & (4) & (5) & (6) & (7) & (8) \\
\hline \multirow{2}{*}{$\begin{array}{l}\text { Lagged dep. } \\
\text { var }\end{array}$} & $0.54^{\star * \star}$ & $0.66^{* * *}$ & $0.49^{* * *}$ & $0.68^{\star * *}$ & $0.62^{\star * *}$ & $0.61^{\star * \star}$ & $0.60^{\star * *}$ & $0.66^{* * *}$ \\
\hline & (126.43) & $(175.73)$ & $(97.67)$ & $(67.60)$ & $(78.00)$ & $(89.57)$ & $(101.27)$ & $(37.95)$ \\
\hline \multirow{2}{*}{$\begin{array}{l}\text { Government } \\
\text { efficiency }\end{array}$} & $0.22^{\star \star \star}$ & $0.06^{\star * \star}$ & $0.47^{\star * \star}$ & $0.21^{\star \star \star}$ & $0.05^{\star \star \star}$ & $0.03^{\star * \star}$ & $0.12^{* * \star}$ & $0.15^{\star \star \star}$ \\
\hline & $(43.63)$ & $(3.73)$ & $(25.53)$ & $(8.77)$ & $(8.91)$ & $(3.07)$ & $(14.98)$ & $(5.52)$ \\
\hline \multirow{2}{*}{ FDI } & 0.03 & $-0.07^{\star}$ & $-0.27^{\star * *}$ & -0.02 & $0.15^{\star \star \star}$ & 0.04 & 0.06 & $-0.33^{\star * *}$ \\
\hline & $(1.53)$ & $(-1.80)$ & $(-7.17)$ & $(-0.15)$ & $(13.60)$ & $(0.77)$ & $(1.08)$ & $(-3.32)$ \\
\hline \multirow{2}{*}{ GDP } & $0.12^{\star * *}$ & & & $0.31^{\star * *}$ & $-0.01^{\star \star \star}$ & & & $0.17^{\star \star}$ \\
\hline & $(80.92)$ & & & $(4.82)$ & $(-6.74)$ & & & $(2.19)$ \\
\hline \multirow{2}{*}{ Openness } & & $-0.17^{* \star \star}$ & & $-0.24^{\star \star \star}$ & & 0.02 & & $0.08^{* \star *}$ \\
\hline & & $(-10.85)$ & & $(-5.47)$ & & $(0.61)$ & & $(2.67)$ \\
\hline \multirow{2}{*}{ Energy } & & $0.01^{\star * \star}$ & & $0.02^{\star * \star}$ & & $-0.01^{\star \star \star}$ & & $-0.02^{\star * *}$ \\
\hline & & $(14.66)$ & & $(4.44)$ & & $(-3.97)$ & & $(-2.92)$ \\
\hline \multirow{2}{*}{ Population } & & & $0.12^{* * *}$ & 0.01 & & & 0.02 & -0.01 \\
\hline & & & $(4.35)$ & $(0.21)$ & & & (1.45) & $(-0.24)$ \\
\hline \multirow{2}{*}{ Education } & & & $0.35^{\star * *}$ & $-0.28^{* * *}$ & & & $0.17^{\star * *}$ & 0.07 \\
\hline & & & $(16.69)$ & $(-3.23)$ & & & $(8.80)$ & $(0.58)$ \\
\hline \multirow[t]{2}{*}{ Industry } & & & $-0.51^{\star * *}$ & $-0.96^{* * *}$ & & & $0.18^{\star \star}$ & $0.63^{* * *}$ \\
\hline & & & $(-5.98)$ & $(-5.16)$ & & & $(2.01)$ & $(2.94)$ \\
\hline \multirow[t]{2}{*}{ Constant } & $-1.31^{\star * *}$ & $-0.67^{\star * *}$ & $-1.67^{\star \star \star *}$ & $-0.50^{* * *}$ & $-0.07^{\star \star \star}$ & -0.02 & $-0.29^{* \star *}$ & $-0.37^{\star \star *}$ \\
\hline & $(-55.10)$ & $(-25.67)$ & $(-25.03)$ & $(-3.75)$ & $(-10.88)$ & $(-0.55)$ & $(-7.25)$ & $(-3.10)$ \\
\hline Sargan test & 0.54 & 0.97 & 0.98 & 0.99 & 0.51 & 0.84 & 0.80 & 0.99 \\
\hline $\mathrm{AR}(1)$ & 0.00 & 0.00 & 0.01 & 0.02 & 0.00 & 0.03 & 0.00 & 0.09 \\
\hline $\operatorname{AR}(2)$ & 0.16 & 0.19 & 0.05 & 0.05 & 0.82 & 0.68 & 0.80 & 0.85 \\
\hline
\end{tabular}

Notes: ${ }^{* * *},{ }^{* *}$, and ${ }^{*}$ indicate statistical significance at the $1 \%, 5 \%$, and $10 \%$ levels, respectively. AR1 and AR2 report the $\mathrm{p}$-value for the Arellano-Bond test of first-order and second-order autocorrelations in the residual of the $(\log )$ patent and trademark applications series. Sargan reports the p-value of the Sargan overidentification test for instrument variables. N represents observations. The lagged dependent variable as the instructment variable.

As expected, whether for the baseline regression or dynamic regression, the proxy variables of Industry and Openness achieve the opposite relationship with patent applications, implying that industrial change and market openness influence patent and trademark applications through different protection and expansion mechanisms. This evidence is consistent with Nasirov (2020). Surprisingly, the variable FDI does not draw a significant influence on innovation output. And more negative coefficients of the indicators of Patent and Trademark, which denote that governments always be cautious with the usage of foreign direct investment. It seems probable that foreign direct investment face a series of constraining under relevant local laws. 
To minimize the interference caused by limitations in the independent variable data and to conduct a more comprehensive empirical analysis, we further verify the effectiveness of governments to enhance the promotion of innovation by replacing the effectiveness of the government with Bureaucracy Quality (BURE), which measures the quality and capacity of the administrative system. Consistent with the above estimation results, improvement in the quality of the bureaucratic system is conducive to growth in the number of patent and trademark applications. The effect of increasing the number of patent applications is also more obvious. The opposite significant impact of population and industrial structure on different innovation indicators may be attributed to differences in the incentive transmission mechanism under institutional adjustments. Surprisingly, a larger-scale export-oriented economy brings more risk factors for patent and trademark infringements, reflecting a negative correlation coefficient of openness. Broadly speaking, improving the quality of the administrative team has a greater promotion effect on innovation which also answers hypothesis 1 .

Table 3. The Impacts of Bureaucracy Quality (ICRG) on Innovation (Fixed Effect)

\begin{tabular}{|c|c|c|c|c|c|c|}
\hline & \multicolumn{3}{|c|}{ LnPatent } & \multicolumn{3}{|c|}{ LnTrademark } \\
\hline & (1) & (2) & (3) & (4) & (5) & (6) \\
\hline \multirow{2}{*}{$\begin{array}{l}\text { Bureaucracy } \\
\text { Quality }\end{array}$} & $0.22^{* *}$ & $0.17^{*}$ & 0.13 & $0.41^{* * *}$ & $0.43^{* * *}$ & $0.54^{* * *}$ \\
\hline & $(2.57)$ & $(1.70)$ & $(1.20)$ & $(6.96)$ & $(6.38)$ & $(7.33)$ \\
\hline \multirow{2}{*}{ FDI } & 0.12 & -0.03 & -0.11 & -0.04 & 0.01 & 0.03 \\
\hline & $(0.37)$ & $(-0.08)$ & $(-0.30)$ & $(-0.20)$ & $(0.06)$ & $(0.16)$ \\
\hline \multirow{2}{*}{ GDP } & $0.41^{* *}$ & $0.57^{* * *}$ & $0.54^{* *}$ & $-0.18^{*}$ & $-0.31^{* *}$ & $-0.43^{* * *}$ \\
\hline & $(2.41)$ & $(2.78)$ & $(2.45)$ & $(-1.75)$ & $(-2.30)$ & $(-2.83)$ \\
\hline \multirow{2}{*}{ Openness } & -0.00 & $-0.12^{* * *}$ & $-0.10^{* *}$ & $-0.04^{* * *}$ & $-0.12^{* * *}$ & $-0.12^{* * \star}$ \\
\hline & $(-0.13)$ & $(-3.30)$ & $(-2.55)$ & $(-2.68)$ & $(-4.82)$ & $(-4.80)$ \\
\hline \multirow{2}{*}{ Energy } & & $0.30^{* *}$ & 0.20 & & $-0.20^{* *}$ & $-0.27^{* *}$ \\
\hline & & $(2.24)$ & $(1.37)$ & & $(-1.98)$ & $(-2.42)$ \\
\hline \multirow{2}{*}{ Population } & & $-0.79^{* *}$ & $-0.66^{*}$ & & 0.13 & 0.06 \\
\hline & & $(-2.35)$ & $(-1.86)$ & & $(0.59)$ & $(0.29)$ \\
\hline \multirow{2}{*}{ Education } & & & -0.03 & & & $0.19^{* * \star}$ \\
\hline & & & $(-0.63)$ & & & $(2.75)$ \\
\hline \multirow{2}{*}{ Industry } & & & $-3.01^{* *}$ & & & 0.10 \\
\hline & & & $(-2.53)$ & & & $(0.13)$ \\
\hline \multirow[t]{2}{*}{ Constant } & $-3.30^{* * *}$ & $-2.25^{* * *}$ & $-1.24^{* *}$ & $-1.01^{* * *}$ & -0.34 & $-0.88^{* *}$ \\
\hline & $(-12.12)$ & $(-4.89)$ & $(-2.09)$ & $(-5.53)$ & $(-1.15)$ & $(-2.21)$ \\
\hline Individual factor & control & control & control & control & control & control \\
\hline Time factor & control & control & control & control & control & control \\
\hline $\mathrm{R} 2$ & 0.02 & 0.07 & 0.08 & 0.07 & 0.11 & 0.13 \\
\hline $\mathrm{F}$ & 3.35 & 6.04 & 5.36 & 14.66 & 10.86 & 10.34 \\
\hline
\end{tabular}

Notes: Trademark denotes the total number of trademark applications, while Patent presents the total number of patent applications. Z-statistics in parenthesis; ${ }^{* * *},{ }^{* *}$, and ${ }^{*}$ indicate statistical significance at the $1 \%, 5 \%$, and $10 \%$ levels, respectively. 
In order to conduct further analysis, the fixed-effect model is replaced with the Poisson model for a robustness check. The Poisson model is:

$$
\begin{aligned}
& \text { Patent }_{i, t}=\alpha_{0}+\alpha_{1} \text { Goveffect }_{i, t}+\beta Z_{i, t}+\mu_{i}+v_{i}+\varepsilon_{i, t} \\
& \text { Trademark }_{i, t}=\alpha_{0}+\alpha_{1} \text { Goveffect }_{i, t}+\beta Z_{i, t}+\mu_{i}+v_{i}+\varepsilon_{i, t} .
\end{aligned}
$$

The estimation results above clearly imply the relationship between government efficiency and innovation. Wen et al. (2018b) indicate that the general panel fixed model is limited by normal distribution among variables. Thus, the analysis using Poisson regression is mainly to prove that the positive correlation between government effectiveness and innovation is still very significant under the condition of diversified distribution, which is also consistent with the results of previous regression analysis. Obviously, after adding a variety of control variables, the factors that can promote innovation output are mainly education and industrial structure.

\begin{tabular}{|c|c|c|c|c|c|c|c|c|}
\hline & \multicolumn{4}{|c|}{ Patent } & \multicolumn{4}{|c|}{ Trademark } \\
\hline & (1) & (2) & (3) & (4) & (5) & (6) & (7) & (8) \\
\hline \multirow{2}{*}{$\begin{array}{l}\text { Government } \\
\text { efficiency }\end{array}$} & $1.41^{\star \star \star}$ & $0.41^{\star \star}$ & $0.44^{\star *}$ & $0.42^{\star *}$ & $0.99^{\star * *}$ & $0.28^{\star \star}$ & $0.46^{\star *}$ & $0.50^{\star \star \star}$ \\
\hline & (11.05) & $(2.39)$ & $(2.57)$ & (1.98) & (9.66) & $(2.10)$ & $(3.58)$ & $(3.27)$ \\
\hline \multirow{2}{*}{ FDI } & 0.76 & $1.39^{*}$ & 0.02 & 0.19 & -0.06 & 0.37 & -0.11 & -0.03 \\
\hline & $(1.50)$ & $(1.85)$ & $(0.03)$ & $(0.22)$ & $(-0.17)$ & $(0.60)$ & $(-0.21)$ & $(-0.04)$ \\
\hline \multirow{2}{*}{ GDP } & $-0.14^{*}$ & & & 0.47 & & & & 0.11 \\
\hline & $(-1.83)$ & & & $(0.47)$ & & & & $(0.24)$ \\
\hline \multirow{2}{*}{ Openness } & & -0.37 & & -0.26 & & -0.18 & & -0.20 \\
\hline & & $(-1.11)$ & & $(-0.59)$ & & $(-0.85)$ & & $(-0.72)$ \\
\hline \multirow{2}{*}{ Energy } & & 0.02 & & 0.03 & & -0.04 & & -0.01 \\
\hline & & $(0.36)$ & & $(0.22)$ & & $(-1.31)$ & & $(-0.10)$ \\
\hline \multirow{2}{*}{ Population } & & & 0.11 & 0.29 & & & 0.13 & 0.15 \\
\hline & & & $(0.45)$ & $(0.59)$ & & & $(1.55)$ & $(0.94)$ \\
\hline \multirow{2}{*}{ Education } & & & $1.84^{* * *}$ & $2.49^{* * *}$ & & & $1.20^{* * *}$ & $2.18^{* * *}$ \\
\hline & & & $(8.13)$ & $(3.73)$ & & & $(8.03)$ & $(4.48)$ \\
\hline \multirow{2}{*}{ Industry } & & & $-2.44^{* *}$ & $-2.99^{* *}$ & & & $-1.31^{* *}$ & -1.09 \\
\hline & & & $(-2.44)$ & $(-1.97)$ & & & $(-2.22)$ & $(-0.92)$ \\
\hline \multirow{2}{*}{ Constant } & $-2.61^{\star * \star}$ & $-3.04^{\star * *}$ & $-2.66^{* * *}$ & $-3.08^{\star * *}$ & $-0.23^{\star * *}$ & $-0.21^{\star * *}$ & $-0.53^{* * *}$ & $-0.92^{\star * *}$ \\
\hline & $(-56.61)$ & $(-18.21)$ & $(-14.59)$ & $(-5.93)$ & $(-9.61)$ & $(-2.87)$ & $(-5.16)$ & $(-4.80)$ \\
\hline
\end{tabular}

Table 4. The Impacts of Government Efficiency (WGI) on Innovation (Poisson Regression)

Notes: Trademark denotes the total number of trademark applications, while Patent presents the total number of patent applications. Z-statistics in parenthesis; ${ }^{* * *},{ }^{* *}$, and ${ }^{*}$ indicate statistical significance at the $1 \%, 5 \%$, and $10 \%$ levels, respectively. 


\subsection{Further analysis}

\subsubsection{Heterogeneity analysis}

As emphasized by scholars such as Chang and Lee (2011), dividing the entire sample into multiple sub-samples with different characteristics can help us to further explore the heterogeneity of social development in various countries. Because innovation activities are often affected by the degree of political openness and economic development. Therefore, we plan to form various contrasts analysis in the level of political, economic, and innovation. According to different development levels and characteristics, we divide the full sample into four sub-sample: former communist countries, European countries, OECD countries, top-10 innovational countries ${ }^{6}$, and reduced sample. Table 5 shows the analysis results. In general, the results obtained by each sub-sample are basically consistent with the entire sample, and improvement in government efficiency can significantly promote innovation output. Similarly, we employ the dynamic estimation for the sub-sample to obtain a longer-term dynamic relationship between innovation output and government effectiveness and to explore several heterogeneities through the generalized method of moments in Table 6. Additionally, it also deals with the endogenous problems in the variables. We chose the lag period of the government efficiency index as the instrumental variable of the model and explored the sustainability of the impact of government efficiency on innovation output. Compared with the estimation results of the former communist countries in the fixed-effect model, the improvement of government efficiency could impact innovation output at the low significance level and even has no significant impact on the number of trademark applications in the dynamic model. From our perspective, it is original from the laws related to patent examination and protection are stricter and more completed than trademark, which will inevitably cause patent applications to be more deeply affected by government intervention in most countries. Therefore, government efficiency has a greater role in promoting the number of patent applications than trademarks. In addition, the promotion of innovation output by efficiency improvement in the governments of former communist countries is more significant, which is mainly due to the characteristics of concentrated political rights and the governance habits formed during their planned economies. This reflects the unsustainability support for innovation activities from political power. Meanwhile, the negative coefficient of the lag phase indicates that the atmosphere of the planned economy has a significant restrictive effect on business innovation, which may stem from increased government intervention for the improvement of government efficiency. The difference in the elasticity of trademarks and patent applications on government efficiency further confirms the difference in development paths between them. From another perspective, it shows that business innovation needs a market-oriented environment. The government should create and maintain a good business environment rather than to pursue economic growth rapidly by mobilizing the large economic resources during the period of economic transformation which also answers hypothesis 2 . Therefore, it also shows that their governments are more inclined to increase innovation output to achieve economic growth.

\footnotetext{
${ }^{6}$ Top 10 innovational countries: United States, China, Japan, Germany, South Korea, France, the United Kingdom, Switzerland, Sweden, and the Netherlands (According the cumulative number of application for patents up to 2018).
} 


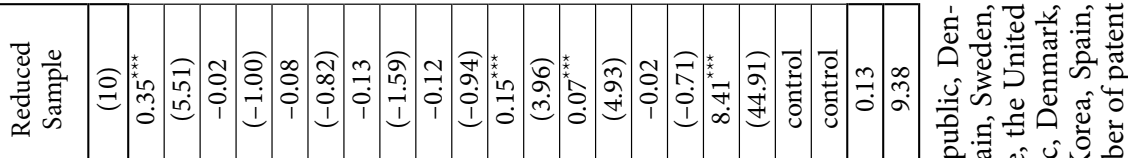

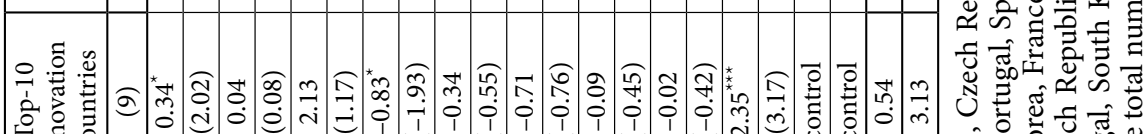

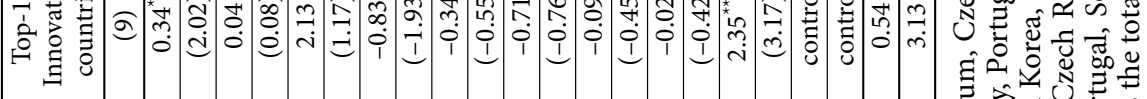

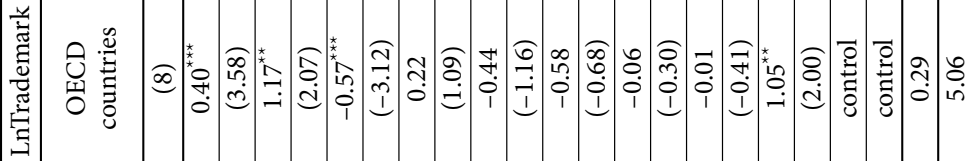

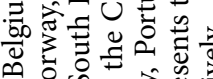
ص⿺辶万人

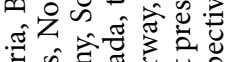

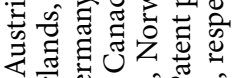

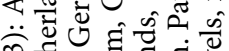

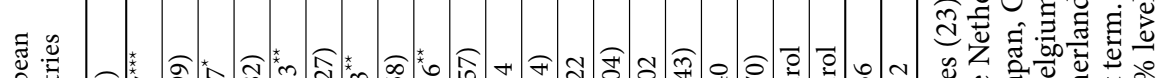

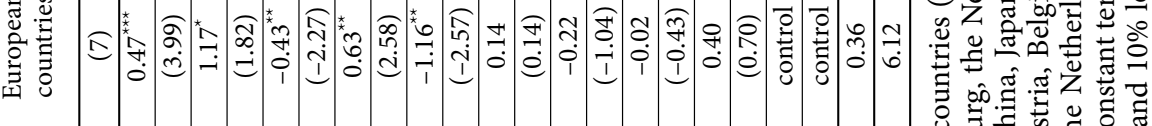

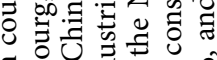

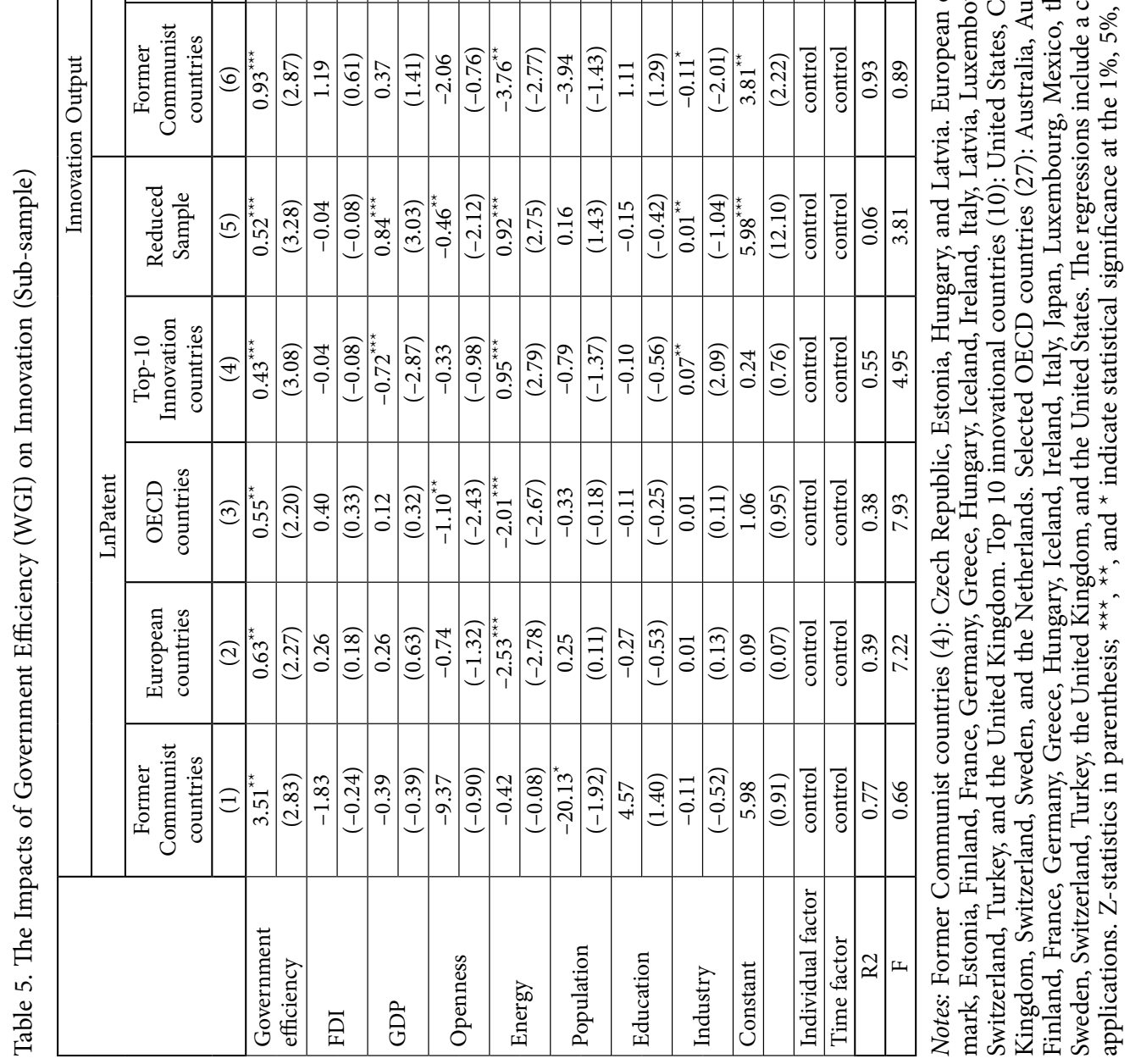




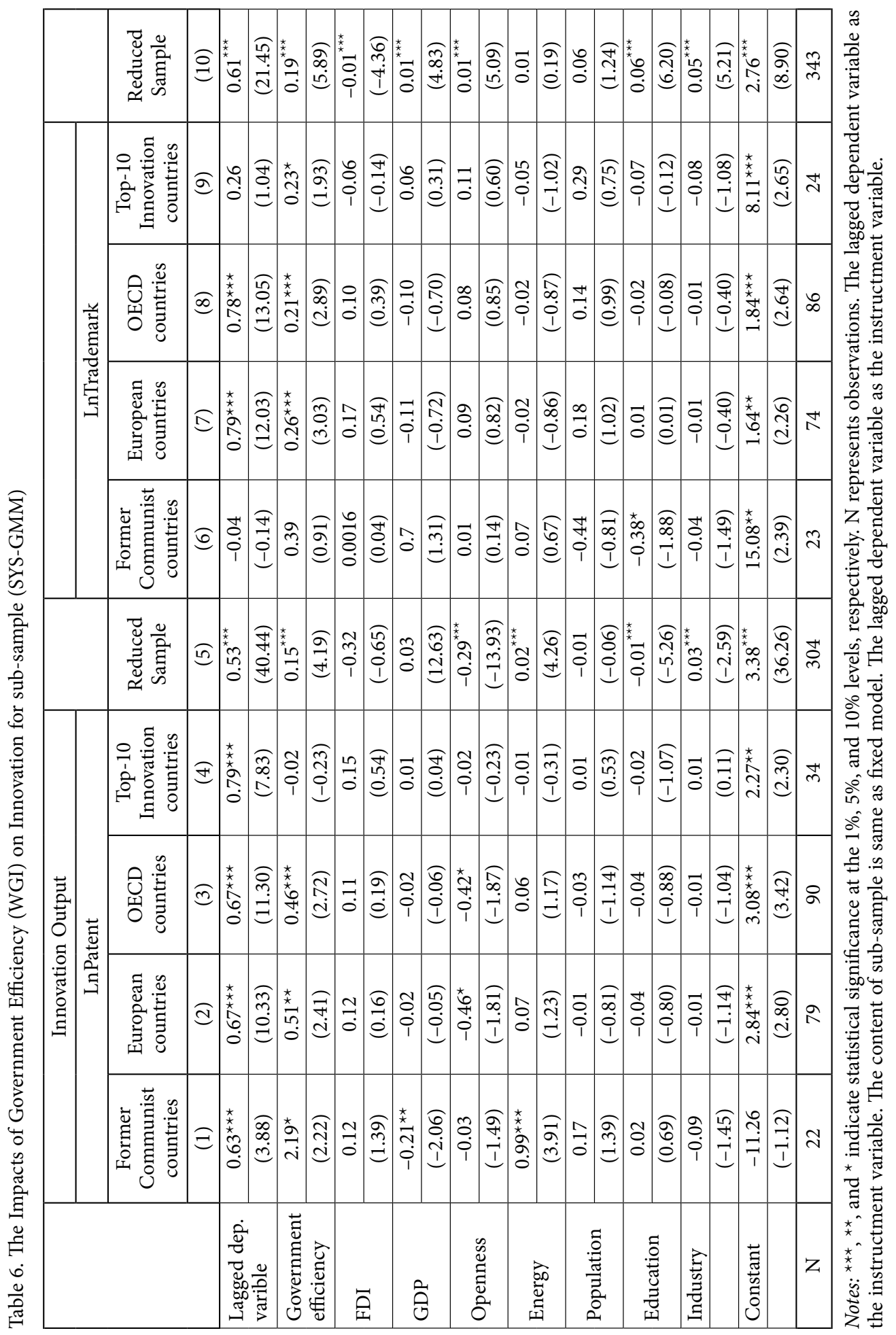


In the sample of EU countries, compared with the former communist countries, European countries generally advocate the concept of "small government, big market". The various resources are allocated by the invisible hand. Therefore, the positive effect of their innovation output from the improvement of government efficiency is limited. The number of trademark applications and the degree of foreign trade openness show more significant positive influences than other regression results. This result may come from the more advertised trademarks by a developed foreign trade system that attracts more businessmen to apply for trademarks.

To confirm whether relatively richer countries pay more attention to investment in innovation, we select 27 OECD countries as the last sub-sample. It can be seen that compared with European countries and former communist countries, the improvement of government effectiveness of OECD countries has less impact on innovation output, which shows that global cooperation has promoted the exchange of technology and capital among countries that weaken the government influence in innovation activities. Obviously, the estimation is very similar to the previous findings.

It is worth noting that the coefficient of government efficiency for high-innovation countries is smaller in the dynamic model than the estimated results of the fixed-effect model. It may be attributed to the countries with higher levels of innovation have a more complete innovation incentive mechanism. Furthermore, in the comparison between static and dynamic regressions, the improvement of government efficiency could stimulate innovation output in the short term. It is convinced that the government could issue a large account of innovation projects and policies to attract more talents to join the innovation team and focus on innovation activities that promote the improvement of innovation output. But more government actions brought by the improvement of government efficiency will interfere with the spontaneous innovation system which may be the reason for the negative coefficient in the dynamic process. On the contrary, in the aspect of trademark-related estimations, the improvement of government efficiency has a limited marginal impact on trademark application in the long run. It is believed that commercial innovation output comes from market forces rather than the government. Thus, although the government efficiency is improved could do a significantly positive impact on the number of trademark applications in the static model, but the final effect still needs the market-testing in the long-term dynamic process. On the other hand, the coefficient of the lag item can verify the stronger the continuity of innovation for high-innovational countries. The smaller coefficient also shows that the market mechanism is the dominant force of innovation rather than political power which confirms the estimated results from previous regressions.

Therefore, we also selected the reduced sample to confirm this conclusion for robustness. And the results of reduced sample regression still reflect the positive effect on innovation output from the improvement of government efficiency. This result also suggests that the administrative teams need to generate well-designed systems and maintain a competitive environment by attracting talents with a greater sense of mission who recognize the social meaning of innovation. For this reason, higher government efficiency and less administrative intervention will bring about a better innovation level. 


\subsubsection{Mechanism analysis}

Compared with the previous heterogeneity study, we will further focus on how government efficiency affects innovation. We choose the system and legal indicators from ICRG as a measurement of the institutional environment. It reflects the degree of investor protection and system integrity. In order to reflect the complementary relationship between the institutional environment and government efficiency, we have added two dependent variables to the model to verify whether government efficiency impacts the local innovation output by improving the institutional environment.

$$
\begin{aligned}
& \text { Ln }\left(\text { Patent }_{i t}\right)=\alpha_{0}+\alpha_{1} \text { Goveffect }_{i, t}+\alpha_{2} \text { system }_{i t}+\alpha_{3} \text { Goveffect }_{i t} \times \\
& \text { system }_{i t}+\beta Z_{i, t}+\mu_{i}+v_{i}+\varepsilon_{i, t} \\
& \operatorname{Ln}\left(\text { Trademark }_{i t}\right)=\alpha_{0}+\alpha_{1} \text { Goveffect }_{i, t}+\alpha_{2} \text { system }_{i t}+\alpha_{3} \text { Goveffect }_{i t} \times \\
& \text { system }_{i t}+\beta Z_{i, t}+\mu_{i}+v_{i}+\varepsilon_{i, t},
\end{aligned}
$$

\begin{tabular}{|c|c|c|c|c|}
\hline & LnPatent & & LnTrademark & \\
\hline & (1) & (2) & (3) & (4) \\
\hline \multirow{2}{*}{$\begin{array}{l}\text { Government } \\
\text { efficiency }\end{array}$} & & $0.87^{* *}$ & & 0.06 \\
\hline & & $(2.50)$ & & $(0.45)$ \\
\hline \multirow{2}{*}{$\begin{array}{l}\text { System } \\
\text { environment }\end{array}$} & $0.04^{* * *}$ & $-0.19^{* * *}$ & $0.08^{\star * *}$ & $-0.06^{* *}$ \\
\hline & $(3.30)$ & $(-2.59)$ & $(7.54)$ & $(-2.27)$ \\
\hline \multirow{2}{*}{$\begin{array}{l}\text { Goveffect* } \\
\text { system }\end{array}$} & & $0.31^{\star * *}$ & & $0.08^{\star * \star}$ \\
\hline & & $(4.08)$ & & $(2.81)$ \\
\hline \multirow{2}{*}{ FDI } & $-0.05^{\star \star \star}$ & -0.63 & $-0.11^{\star \star \star}$ & -0.02 \\
\hline & $(-8.67)$ & $(-1.08)$ & $(-18.70)$ & $(-0.09)$ \\
\hline \multirow{2}{*}{ GDP } & $0.01^{* * *}$ & $0.10^{\star * *}$ & $0.01^{\star * *}$ & 0.01 \\
\hline & $(2.59)$ & $(3.50)$ & $(3.92)$ & $(0.48)$ \\
\hline \multirow{2}{*}{ Openness } & $-0.11^{\star * \star}$ & -0.30 & $0.03^{* *}$ & -0.06 \\
\hline & $(-4.09)$ & $(-1.49)$ & $(2.17)$ & $(-0.79)$ \\
\hline \multirow{2}{*}{ Energy } & 0.04 & 0.55 & -0.06 & -0.21 \\
\hline & $(0.58)$ & $(1.45)$ & $(-0.64)$ & $(-1.41)$ \\
\hline \multirow{2}{*}{ Education } & $0.08^{\star *}$ & -0.23 & $0.45^{\star * *}$ & $0.80^{\star \star *}$ \\
\hline & $(2.39)$ & $(-0.59)$ & $(10.53)$ & (5.15) \\
\hline \multirow{2}{*}{ Industry } & -0.03 & -0.13 & $0.64^{\star * *}$ & -0.25 \\
\hline & $(-0.28)$ & $(-1.28)$ & $(5.86)$ & $(-0.80)$ \\
\hline \multirow{2}{*}{ _cons } & $1.62^{x * *}$ & $7.17^{* * *}$ & $2.74^{\star * *}$ & $8.95^{\star * *}$ \\
\hline & $(9.44)$ & $(12.35)$ & $(16.26)$ & $(40.36)$ \\
\hline $\mathrm{N}$ & 561 & 458 & 617 & 484 \\
\hline
\end{tabular}

where $\mu_{i}$ represents unobserved factors with no timely change that is used to control regional fixed effects, and $v_{i}$ is used to control time fixed effects.

Table 7. Innovation output, system environment and government efficiency

Notes: Trademark denotes the total number of trademark applications, while Patent presents the total number of patent applications. Z-statistics in parenthesis; ${ }^{* * *},{ }^{* *}$, and ${ }^{*}$ indicate statistical significance at the $1 \%, 5 \%$, and $10 \%$ levels, respectively. 
From the regression model shown in Table 7, column (1) and (3) show that the institutional environment has a significant promotion effect on innovation output, and the institutional environment has a more significant promotion effect on business innovation, both of which meet the $1 \%$ significance test. This shows that a good institutional environment can significantly increase local innovation output. On the other hand, by exploring the interaction between the institutional environment and government effectiveness in columns (2) and (4), we can find that the institutional environment and government efficiency have a significant complementary effect on innovation activities. It also further verifies that the government can promote innovation activities by optimizing the institutional environment which answers hypothesis 3 .

From the above results, it can be concluded that whether the benchmark regression or the robustness check results show that the improvement of government efficiency can increase innovation output. In addition, the use of different government performance indicators and estimation methods have verified that the improvement of government efficiency has a continuous role in promoting innovation. After checking the sub-samples, several heterogeneous conclusions can be drawn, for example, in regions with a culture of a planned economy, the improvement of government efficiency would play important role in innovation development. In addition, in regions with a high level of innovation, the promotion of government efficiency to promote innovation output is limited, which shows that developed and innovative regions are forming a virtuous circle of spontaneous innovation activity. Finally, the mechanism test suggests that government could improve innovation output by optimizing related laws and systems.

\section{Conclusions}

This study tests the effects of government efficiency on innovation output using the fixed effect model, dynamic GMM estimation, and Poisson model for 166 countries during 19962018. The education, per capita GDP, energy density, and openness-related indicators have been utilized as explanatory variables to more closely characterize the relationship between government effectiveness and innovation output. The results show that among the 166 sample countries, the variables GDP, Industry, and Energy always generate different impacts on trademark and patent applications.

This paper further explores the sub-sample set of former communist countries, European countries, OECD countries, and top-10 innovational countries to test the robustness of the model, offering several surprising findings. The sub-sample regression proves the robustness of the benchmark model, and more importantly, the dynamic model illustrates the long-term positive correlation between government effectiveness and innovation output. Concretely, through the robustness test is conducted, we find that improvement in the efficiency of administrative power in the former communist countries has a more prominent impact on the output of innovation output. This also suggests that research on the concentration of political rights and on the impact of a democratic environment on innovation is valuable.

We obtain the conclusion from researching the government effectiveness of selected countries that improvement in government effectiveness mainly comes from the optimization of the system, the improvement of the education of government staff, and the stream- 
lining of the approval process. Therefore, to further improve the output of innovation in the future, we should start by optimizing the institutional environment, transform government functions, attract more innovative talents, and rely on an active atmosphere for innovation and entrepreneurship.

Therefore, our findings also provide implications to an ambitious government for upgrading the innovation level. Firstly, human capital is a vital factor in the process of efficiency promotion. Thus government should attract highly educated personnel to join them and conduct regular innovative training for government employees. The officers should clarify the boundary between the government and enterprises and play the role of guidance and service. Secondly, the appreciated innovation policies and coherent project approval process could give entrepreneurs more support through the reformation of a transparent operating system. However, due to the rotation of political parties, the instability of policies and political power hinders or excessively interferes with the development of innovation activities. Therefore, it is particularly important to establish a long-term incentive mechanism by market power for innovation activities. In addition, based on the high-risk characteristics of innovative research projects, innovative projects often face the problem of limited financing channels. What is more important is to force the government to build and improve the digital matching system among funds and research projects to achieve the higher innovation level. Finally, the government should improve the Intellectual Property Protection Law to regulate inappropriate competition and maintain a fair market environment.

There are additionally several limitations in this paper. First, the sample size is limited and only for international data. Second, although a sub-sample test is conducted on the sampled countries, the exploration of individual economies is insufficient. Third, this paper only explores an impact mechanism in which government efficiency promotes innovation output through system optimization and does not conduct a more diversified mechanism testing approach. Thus, scholars in the future can conduct research on how to improve government efficiency and build a digital governance environment based on this paper. In order to promote innovation output, researchers should highlight topics about policy design of patents and trademarks. Most importantly, better alternative impact mechanisms between innovation and government for individual countries could be explored in subsequent research.

\section{Acknowledgments}

The authors are very grateful to three anonymous reviewers and editor for their insightful comments that helped us sufficiently improve the quality of this paper. Jun Wen is grateful to the National Natural Science Foundation of China for the grant [number 72074176 and $71673216]$.

\section{References}

Arellano, M., \& Bond, S. R. (1991). Some tests of specification for panel data: monte carlo evidence and an application to employment equations. Review of Economic Studies, 58(2), 277-297. https://doi.org/10.2307/2297968

Acemoglu, D., Naidu, S., Restrepo, P., \& Robinson, J. A. (2019). Democracy does cause growth. Journal of Political Economy, 127(1), 47-100. https://doi.org/10.1086/700936 
Aghion, P., Alesina, A. F., \& Trebbi, F. (2007). Democracy, technology, and growth (Working Paper No. 13180). National Bureau of Economic Research. https://doi.org/10.3386/w13180

Archibugi, D., \& Filippetti, A. (2013). Innovation and economic crisis: lessons and prospects from the economic downturn. Routledge. https://doi.org/10.4324/9780203804513

Aghion, P., Bergeaud, A., Lequien, M., \& Melitz, M. J. (2018). The impact of exports on innovation: theory and evidence (Working Paper No. 24600). National Bureau of Economic Research. https://doi.org/10.2139/ssrn.3171084

Anokhin, S., \& Wincent, J. (2012). Start-up rates and innovation: a cross-country examination. Journal of International Business Studies, 43(1), 41-60. https://doi.org/10.1057/jibs.2011.47

Ayres, R. U., Turton, H., \& Casten, T. (2007). Energy efficiency, sustainability and economic growth. Energy, 32, 634-648. https://doi.org/10.1016/j.energy.2006.06.005

Akisik, O., Gal, G., \& Mangaliso, M. P. (2020). IFRS, FDI, economic growth and human development: The experience of Anglophone and Francophone African countries. Emerging Markets Review, 45, 100725. https://doi.org/10.1016/j.ememar.2020.100725

Autor, D., Dorn, D., Hanson, G. H., Pisano, G., \& Shu, P. (2016). Foreign competition and domestic innovation: evidence from Us patents (Working Paper No. 22879). National Bureau of Economic Research. https://doi.org/10.3386/w22879

Audretsch, D. B., Lehmann, E. E., \& Wright, M. (2014). Technology transfer in a global economy. Journal of Technology Transfer, 39(3), 301-312. https://doi.org/10.1007/s10961-012-9283-6

Angelini, F., Candela, G., \& Castellani, M. (2020). Governance efficiency with and without government. Social Choice and Welfare, 54(1), 183-200. https://doi.org/10.1007/s00355-019-01217-2

Baskaran, A., \& Muchie, M. (2006). The impact of the national innovation systems on the flow and benefits of foreign direct investment to national economies. Georgia Institute of Technology.

Belke, A., \& Potrafke, N. (2012). Does government ideology matter in monetary policy? A panel data analysis for OECD countries. Journal of International Money and Finance, 31(5), 1126-1139. https://doi.org/10.1016/j.jimonfin.2011.12.014

Bronzini, R., \& Piselli, P. (2016). The impact of R\&D subsidies on firm innovation. Research Policy, 45(2), 442-457. https://doi.org/10.1016/j.respol.2015.10.008

Bianchi, N., \& Giorcelli, M. (2020). Scientific education and innovation: from technical diplomas to university STEM degrees. Journal of the European Economic Association, 18(5), 2608-2646. https://doi.org/10.1093/jeea/jvz049

Benny, V. (2020). The impact of patent, trademark and industrial design applications in Indian Economy. Gedrag \& Organisatie Review, 33(2), 2399-2411. https://doi.org/10.37896/GOR33.02/244

Chang, C. P., \& Lee, C. C. (2011). The effect of globalization and political party on economic growth panel data analysis of former communist countries and European OECD members. Eastern European Economics, 49(6), 5-26. https://doi.org/10.2753/EEE0012-8775490601

Chang, C.-P., Wen, J., Zheng, M., Dong, M., \& Hao, Y. (2018). Is higher government efficiency conducive to improving energy use efficiency? Evidence from OECD countries. Economic Modelling, 72, 65-77. https://doi.org/10.1016/j.econmod.2018.01.006

Chang, C. P., Lee, C. C., \& Berdiev, A. (2015). The impact of government ideology on energy efficiency: evidence from panel data. Energy Efficiency, 8(6), 1181-1199. https://doi.org/10.1007/s12053-015-9347-1

Chi, W., \& Qian, X. (2010). The role of education in regional innovation activities: spatial evidence from China. Journal of the Asia Pacific Economy, 15(4), 396-419. https://doi.org/10.1080/13547860.2010.516158

Dahlander, L., \& Gann, D. M. (2010). How open is innovation? Reserach Policy, 39(6), 699-709. https://doi.org/10.1016/j.respol.2010.01.013 
Dong, J., Li, W., Cao, Y., \& Fang, J. (2016). How does technology and population progress relate? An empirical study of the last 10,000 years. Technological Forecasting and Sociale Change, 103(4), 57-70. https://doi.org/10.1016/j.techfore.2015.11.011

Dong, R. R., \& Martin, A. (2017). Research on barriers and government driving force in technological innovation of architecture based on BIM. EURASIA Journal of Mathematics Science and Technology Education, 13(8), 5757-5763. https://doi.org/10.12973/eurasia.2017.01025a

Dolfsma, W., \& Seo, D. B. (2013). Government policy and technological innovation-a suggested typology. Technovation, 33(6-7), 173-179. https://doi.org/10.1016/j.technovation.2013.03.011

Duygun, M., Sena, V., \& Shaban, M. (2016). Trademarking activities and total factor productivity: some evidence for British commercial banks using a metafrontier approach. Journal of Banking \& Finance, 72, S70-S80. https://doi.org/10.1016/j.jbankfin.2016.04.017

Donou-Adonsou, F. (2019). Technology, education, and economic growth in Sub-Saharan Africa. Telecommunications Policy, 43(4), 353-360. https://doi.org/10.1016/j.telpol.2018.08.005

Flanagan, K., Uyarra, E., \& Laranja, M. (2011). Reconceptualising the 'policy mix' for innovation. Research Policy, 40(5), 702-713. https://doi.org/10.1016/j.respol.2011.02.005

Furman, J. L., Porter, M. E., \& Stern, S. (2002). The determinants of national innovative capacity. Research Policy, 31(6), 899-933. https://doi.org/10.1016/S0048-7333(01)00152-4

Fredriksson, P. G., \& Svensson, J. (2003). Political instability, corruption and policy formation: the case of environmental policy. Journal of Public Economics, 87(7-8), 1383-1405. https://doi.org/10.1016/S0047-2727(02)00036-1

Fuenfschilling, L., \& Truffer, B. (2014). The structuration of socio-technical regimes-conceptual foundations from institutional theory. Research Policy, 43(4), 772-791. https://doi.org/10.1016/j.respol.2013.10.010

Farre-Mensa, J., Hegde, D., \& Ljungqvist, A. (2020). What is a patent worth? Evidence from the US patent "lottery". The Journal of Finance, 75(2), 639-682. https://doi.org/10.1111/jofi.12867

Geroski, P. A., \& Walters, C. F. (1995). Innovative activity over the business cycle. The Economic Journal, 105(431), 916-928. https://doi.org/10.2307/2235158

Godfrey, M., Sophal, C., Kato, T., Piseth, L. V., Dorina, P., Saravy, T., \& Sovannarith, S. (2002). Technical assistance and capacity development in an aid-dependent economy: the experience of Cambodia. World Development, 30(3), 355-373. https://doi.org/10.1016/S0305-750X(01)00121-8

Galang, R. M. N. (2012). Government efficiency and international technology adoption: the spread of electronic ticketing among airlines. Journal of International Business Studies, 43(7), 631-654. https://doi.org/10.1057/jibs.2012.20

Glotko, A. V., Polyakova, A. G., \& Kuznetsova, M. Y. (2020). Main trends of government regulation of sectoral digitalization. Entrepreneurship and Sustainability Issues, 7(3), 2181-2195. https://doi.org/10.9770/jesi.2020.7.3(48)

Haas, C., \& Kempa, K. (2016). Directed technical change and energy intensity dynamics: structural change Vs. Energy efficiency (MAGKS Discussion Paper Series in Economics No. 10). https://doi.org/10.2139/ssrn.2788055

Howell, A. (2020). Industry relatedness, FDI liberalization and the indigenous innovation process in China. Regional Studies, 54(2), 229-243. https://doi.org/10.1080/00343404.2019.1623871

Hung, K. P., \& Chou, C. (2013). The impact of open innovation on firm performance: the moderating effects of internal R\&D and environmental turbulence. Technovation, 33(10-11), 368-380. https://doi.org/10.1016/j.technovation.2013.06.006

Hudson, J., \& Minea, A. (2013). Innovation, intellectual property rights, and economic development: a unified empirical investigation. World Development, 46, 66-78. https://doi.org/10.1016/j.worlddev.2013.01.023

Hille, E., Althammer, W., \& Diederich, H. (2020). Environmental regulation and innovation in renewable energy technologies: Does the policy instrument matter? Technological Forecasting and Social Change, 153, 119921. https://doi.org/10.1016/j.techfore.2020.119921 
Jalles, J. T. (2010). How to measure innovation? new evidence of the technology-growth linkage. Research in Economics, 64(2), 81-96. https://doi.org/10.1016/j.rie.2009.10.007

Kayal, A. A. (2016). R\&D Intensity: an empirical analysis of its relation to the structure of the manufacturing sector in OECD countries. International Journal of Technology Management \& Sustainable Development, 15(1), 61-81. https://doi.org/10.1386/tmsd.15.1.61_1

Kaiser, U., Kongsted, H. C., \& Rønde, T. (2015). Does the mobility of R\&D labor increase innovation? Journal of Economic Behavior \& Organization, 110, 91-105. https://doi.org/10.1016/j.jebo.2014.12.012

Kogan, L., Papanikolaou, D., Seru, A., \& Stoffman, N. (2017). Technological innovation, resource allocation, and growth. The Quarterly Journal of Economics, 132(2), 665-712. https://doi.org/10.1093/qje/qjw040

Kuhn, T. S. (2012). The structure of scientific revolutions. University of Chicago Press. https://doi.org/10.7208/chicago/9780226458144.001.0001

Lehmann, E. E., \& Seitz, N. (2017). Freedom and innovation: a country and state level analysis. The Journal of Technology Transfer, 42(5), 1009-1029. https://doi.org/10.1007/s10961-016-9478-3

Lin, B., \& Du, K. (2013). Technology gap and China's regional energy efficiency: a parametric metafrontier approach. Energy Economics, 40, 529-536. https://doi.org/10.1016/j.eneco.2013.08.013

Li, B. Y., Hao, Y., \& Chang, C. P. (2017). Does an anticorruption campaign deteriorate environmental quality? Evidence from China. Energy \& Environment, 29(1). https://doi.org/10.1177/0958305X17740717

Luo, J., \& Cheng, K. (2013). The influence of FDI on energy efficiency of China: an empirical analysis based on DEA method. Applied Mechanics and Materials, 291-294, 1217-1220.

https://doi.org/10.4028/www.scientific.net/AMM.291-294.1217

Lee, C. Y. (2010). A theory of firm growth: learning capability, knowledge threshold, and patterns of growth. Research Policy, 39(2), 278-289. https://doi.org/10.1016/j.respol.2009.12.008

Lachenmaier, S., \& Rottmann, H. (2011). Effects of innovation on employment: a dynamic panel analysis. International Journal of Industrial Organization, 29(2), 210-220. https://doi.org/10.1016/j.ijindorg.2010.05.004

Lovett, K. (2011). Institutional design and economic growth: the relationship between bureaucracy and economic performance in a global economy (Working Paper). https://people.carleton.edu/ amontero/ Kelly\%20Lovett.pdf

Mendonça, S. (2012). Trademarks as a telecommunications indicator for industrial analysis and policy. In Telecommunication economics (pp. 33-41). Springer. https://doi.org/10.1007/978-3-642-30382-1_6

Murphy, K. M., Shleifer, A., \& Vishny, R. W. (1993). Why is rent-seeking so costly to growth? The American Economic Review, 83(2), 409-414.

Musiolik, J., Markard, J., \& Hekkert, M. (2020). Creating innovation systems: How resource constellations affect the strategies of system builders. Technological Forecasting and Social Change, 153, 119209. https://doi.org/10.1016/j.techfore.2018.02.002

Murray, F., Aghion, P., Dewatripont, M., Kolev, J., \& Stern, S. (2016). Of mice and academics: examining the effect of openness on innovation. American Economic Journal: Economic Policy, 8(1), 212-252. https://doi.org/10.1257/pol.20140062

Melero, E., Palomeras, N., \& Wehrheim, D. (2020). The effect of patent protection on inventor mobility. Management Science, 66(12), 5485-5504. https://doi.org/10.1287/mnsc.2019.3500

Nickell, S. (1981). Biases in dynamic models with fixed effects. Econometrica, 49(6), 1417-1426. https://doi.org/10.2307/1911408

Nasirov, S. (2020). Trademark value indicators: Evidence from the trademark protection lifecycle in the US pharmaceutical industry. Research Policy, 49(4), 103929.

https://doi.org/10.1016/j.respol.2020.103929 
Parrotta, P., Pozzoli, D., \& Pytlikova, M. (2014). The nexus between labor diversity and firm's innovation. Journal of Population Economics, 27(2), 303-364. https://doi.org/10.1007/s00148-013-0491-7

Picazo-Tadeo, A. J., González-Gómez, F., Wanden-Berghe, J. G., \& Ruiz-Villaverde, A. (2012). Do ideological and political motives really matter in the public choice of local services management? Evidence from urban water services in Spain. Public Choice, 151(1), 215-228. https://doi.org/10.1007/s11127-010-9744-0

Pradhan, R. P., Arvin, M. B., Hall, J. H., \& Nair, M. (2016). Innovation, financial development and economic growth in Eurozone countries. Applied Economics Letters, 23(16), 1141-1144. https://doi.org/10.1080/13504851.2016.1139668

Rydgren, J. (2005). Is extreme right-wing populism contagious? Explaining the emergence of a new party family. European Journal of Political Research, 44(3), 413-437.

https://doi.org/10.1111/j.1475-6765.2005.00233.x

Romer, P. M. (1990). Endogenous technological change. Journal of Political Economy, 98(5), 71-102. https://doi.org/10.1086/261725

Sena, V., Duygun, M., Lubrano, G., Marra, M., \& Shaban, M. (2018). Board independence, corruption and innovation. Some evidence on UK subsidiaries. Journal of Corporate Finance, 50, 22-43. https://doi.org/10.1016/j.jcorpfin.2017.12.028

Samara, E., Georgiadis, P., \& Bakouros, I. (2012). The impact of innovation policies on the performance of national innovation systems: a system dynamics analysis. Technovation, 32(11), 624-638. https://doi.org/10.1016/j.technovation.2012.06.002

Sekmen, F., \& Toptas, M. (2015). Education, technical progress, and economic growth in the information age: the case of Turkey. International Journal of Social Ecology and Sustainable Development, 6(1), 73-84. https://doi.org/10.4018/ijsesd.2015010106

Smith, A., Voß, J. P., \& Grin, J. (2010). Innovation studies and sustainability transitions: the allure of the multi-level perspective and its challenges. Research Policy, 39(4), 435-448. https://doi.org/10.1016/j.respol.2010.01.023

Stim, R. (2020). Patent, copyright \& trademark: an intellectual property desk reference. Nolo.

Wen, J., Zheng, M., Feng, G.-F., Chen, S. W., \& Chang, C.-P. (2018a). Corruption and innovation: linear and nonlinear investigations of OECD Countries. The Singapore Economic Review, 1-27.

Wen, J., Feng, G. F., Chang, C. P., \& Feng, Z. Z. (2018b). Stock liquidity and enterprise innovation: new evidence from China. The European Journal of Finance, 24(9), 683-713. https://doi.org/10.1080/1351847X.2017.1347573

Wen, J., Hao, Y., Feng, G. F., \& Chang, C. P. (2016). Does government ideology influence environmental performance? Evidence based on a new dataset. Economic Systems, 40(2), 232-246. https://doi.org/10.1016/j.ecosys.2016.04.001

Wang, Q. L., Feng, G. F., Wen, J., \& Chang, C. P. (2019). The impacts of government ideology on innovation: what are the main implications? Research Policy, 48(5), 1232-1247. https://doi.org/10.1016/j.respol.2018.12.009

Wang, S., Zhao, D., \& Chen, H. (2020). Government corruption, resource misallocation, and ecological efficiency. Energy Economics, 85, 104573. https://doi.org/10.1016/j.eneco.2019.104573

Wooldridge, J. M. (2015). Introductory econometrics: a modern approach. Nelson Education.

World Bank. (2018). The little data. World Bank Publications.

WDI. (2018). http://databank.worldbank.org/data/reports.aspx?source=wdi-databasearchives-(beta)

Ziller, C., \& Goodman, S. W. (2020). Local government efficiency and anti-immigrant violence. The Journal of Politics, 82(3), 895-907. https://doi.org/10.1086/707399

Zaichkowsky, J. L. (2020). The psychology behind trademark infringement and counterfeiting. Psychology Press. https://doi.org/10.4324/9781315820965 


\section{APPENDIX}

Table A1. Correlation matrix

\begin{tabular}{|l|c|c|c|c|c|c|c|c|c|c|c|c|}
\hline & WGI & ICRG & FDI & GDP & $\begin{array}{c}\text { Popula- } \\
\text { tion }\end{array}$ & $\begin{array}{c}\text { Edu- } \\
\text { cation }\end{array}$ & $\begin{array}{c}\text { Indus- } \\
\text { try }\end{array}$ & $\begin{array}{c}\text { Open- } \\
\text { ness }\end{array}$ & $\begin{array}{c}\text { En- } \\
\text { ergy }\end{array}$ & $\begin{array}{c}\text { Sys- } \\
\text { tem }\end{array}$ & VIF & $\begin{array}{c}\text { Toler- } \\
\text { ance }\end{array}$ \\
\hline WGI & 1 & & & & & & & & & & 1.06 & 0.94 \\
\hline ICRG & -0.04 & 1 & & & & & & & & & 1.15 & 0.86 \\
\hline FDI & -0.02 & 0.01 & 1 & & & & & & & & 1.66 & 0.60 \\
\hline GDP & 0.09 & -0.07 & 0.07 & 1 & & & & & & & 1.79 & 0.55 \\
\hline Population & -0.03 & -0.06 & 0.04 & 0.45 & 1 & & & & & & 1.78 & 0.56 \\
\hline Education & 0.02 & 0.06 & 0.09 & 0.56 & 0.11 & 1 & & & & & 2.16 & 0.46 \\
\hline Industry & -0.07 & -0.01 & -0.03 & 0.06 & -0.13 & 0.07 & 1 & & & & 1.24 & 0.80 \\
\hline Openness & -0.06 & 0.02 & 0.32 & 0.22 & 0.41 & 0.27 & -0.02 & 1 & & & 1.88 & 0.53 \\
\hline Energy & -0.08 & 0.00 & -0.06 & -0.22 & -0.12 & -0.23 & 0.08 & -0.13 & 1 & & 1.19 & 0.84 \\
\hline System & 0.46 & -0.01 & -0.01 & 0.17 & -0.01 & 0.08 & -0.04 & 0.08 & 0.07 & 1 & 2.78 & 0.35 \\
\hline
\end{tabular}

Notes: WGI represents government efficiency (WGI). ICRG represents bureaucracy quality (ICRG). GDP represents real per capita GDP.

Table A2. Data sources and descriptive statistics

\begin{tabular}{|l|l|l|c|c|c|}
\hline \multicolumn{1}{|c|}{ Variable } & \multicolumn{1}{|c|}{ Definition } & \multicolumn{1}{|c|}{ Source } & Mean & S. Deviation & Observation \\
\hline Patent & Patent applications & $\begin{array}{l}\text { World Intellectual } \\
\text { Property } \\
\text { Organization } \\
\text { (WIPO) Patent } \\
\text { Report }\end{array}$ & 13954.33 & 68586.43 & 3,617 \\
\hline Trademark & $\begin{array}{l}\text { Trademark } \\
\text { applications }\end{array}$ & $\begin{array}{l}\text { World Intellectual } \\
\text { Property } \\
\text { Organization } \\
\text { (WIPO) Patent } \\
\text { Report }\end{array}$ & 20689.16 & 72127.16 & 4,068 \\
\hline $\begin{array}{l}\text { Government } \\
\text { efficiency }\end{array}$ & $\begin{array}{l}\text { Ranging from } \\
\text { approximately }-2.5 \\
\text { to 2.5; higher values } \\
\text { represent greater } \\
\text { government efficiency }\end{array}$ & $\begin{array}{l}\text { World Governance } \\
\text { Indicators }\end{array}$ & 0.019 & 1.02 & 3,894 \\
\hline Bure & Bureaucracy Quality & $\begin{array}{l}\text { International } \\
\text { Country Risk Guide }\end{array}$ & 2.12 & 1.16 & 4,172 \\
\hline $\begin{array}{l}\text { Institutional } \\
\text { Environment }\end{array}$ & Law and Order & $\begin{array}{l}\text { International } \\
\text { Country Risk Guide }\end{array}$ & 3.96 & 1.43 & 3539 \\
\hline FDI & $\begin{array}{l}\text { Foreign direct } \\
\text { investment, net } \\
\text { inflows (\% of GDP) }\end{array}$ & $\begin{array}{l}\text { World Development } \\
\text { Indicators (WDI) }\end{array}$ & 4.69 & 30.46 & 4,704 \\
\hline GDP & $\begin{array}{l}\text { GDP per capita } \\
\text { (constant 2010 US\$) }\end{array}$ & $\begin{array}{l}\text { World Development } \\
\text { Indicators (WDI) }\end{array}$ & 10467.23 & 17056.86 & 5,795 \\
\hline
\end{tabular}


End of Table A2

\begin{tabular}{|l|l|l|c|c|c|}
\hline Variable & \multicolumn{1}{|c|}{ Definition } & \multicolumn{1}{c|}{ Source } & Mean & S. Deviation & Observation \\
\hline Population & $\begin{array}{l}\text { Population density } \\
\text { (people per sq. km of } \\
\text { land area) }\end{array}$ & $\begin{array}{l}\text { World Bank } \\
\text { population estimates }\end{array}$ & 267.56 & 1317.57 & 7,547 \\
\hline Education & $\begin{array}{l}\text { School enrollment, } \\
\text { secondary (\% gross) }\end{array}$ & $\begin{array}{l}\text { UNESCO Institute } \\
\text { for Statistics }\end{array}$ & 62.39 & 32.32 & 4,149 \\
\hline Industry & $\begin{array}{l}\text { Industry (including } \\
\text { construction), value } \\
\text { added (\% of GDP) }\end{array}$ & $\begin{array}{l}\text { World Development } \\
\text { Indicators (WDI) }\end{array}$ & 27.10 & 12.25 & 4,649 \\
\hline Openness & $\begin{array}{l}\text { Sum of exports and } \\
\text { Imports of goods and } \\
\text { services (\% of GDP) }\end{array}$ & $\begin{array}{l}\text { World Development } \\
\text { Indicators (WDI) }\end{array}$ & 73.95 & 50.40 & 5,263 \\
\hline Energy & $\begin{array}{l}\text { Energy intensity level } \\
\text { of primary energy } \\
\text { (MJ/\$2011 PPP GDP) }\end{array}$ & $\begin{array}{l}\text { World Development } \\
\text { Indicators (WDI) }\end{array}$ & 6.84 & 5.31 & 3,016 \\
\hline
\end{tabular}

List A3. The country list (full sample)

Albania, Austria, Bahamas, Bahrain, Bangladesh, Barbados, Belarus, Belgium, Belize, Bhutan, Bolivia, Bosnia and Herzegovina, Botswana, Brazil, Brunei Darussalam, Bulgaria, Burkina Faso, Burundi, Canada, Chile, China, Colombia, Congo, Dem. Rep, Congo, Rep, Costa Rica, Côte d'Ivoire, Croatia, Cuba, Cyprus, Czech Republic, Denmark, Djibouti, Dominica, Dominican Republic, Ecuador, Egypt, Arab Rep., El Salvador, Eritrea, Estonia, Ethiopia, Fiji, Finland, France, French, Guiana, Gambia, Georgia, Germany, Ghana, Greece, Greenland, Grenada, Guam, Guatemala, Guinea, Guinea-Bissau, Guyana, Haiti, Honduras, Hong Kong SAR. China, Hungary, Iceland, India, Indonesia, Iran, Iraq, Ireland, Israel, Italy, Jamaica, Japan, Jersey. Channel Islands, Jordan, Kazakhstan, Kenya, Kiribati, Korea, Dem. Rep., Korea, Rep., Kosovo, Kuwait, Kyrgyz Republic, Lao PDR, Latvia, Lebanon, Lesotho, Liberia, Libya, Liechtenstein, Lithuania, Luxembourg, Macao SAR. China, Madagascar, Malawi, Malaysia, Mali, Malta, Mauritania, Mauritius, Mexico, Moldova, Monaco, Mongolia, Montenegro, Morocco, Mozambique, Namibia, Nepal, Netherlands, New Zealand, Nicaragua, Niger, Norway, Oman, Pakistan, Panama, Papua New Guinea, Paraguay, Peru, Philippines, Poland, Portugal, Qatar, Romania, Russian Federation, Rwanda, Samoa, São Tomé and Principe, Saudi Arabia, Senegal, Serbia, Sierra Leone, Singapore, Slovak Republic, Slovenia, South Africa, South Sudan, Spain, Sri Lanka, St. Kitts and Nevis, St. Lucia, St. Vincent and the Grenadines, Sudan, Suriname, Sweden, Switzerland, Syrian Arab Republic, Tanzania, Thailand, Tonga, Trinidad and Tobago, Tunisia, Turkey, Turkmenistan, Uganda, Ukraine, United Arab Emirates, United Kingdom, United States, Uruguay, Uzbekistan, Venezuela RB, Vietnam, Yemen Rep, Zambia, Zimbabwe. 